\title{
Fırat Havzası'ndaki Meteorolojik ve Hidrolojik Kuraklık Haritalarının Çeşitli Enterpolasyon Metotları ile Belirlenmesi
}

\author{
Okan Mert Katipoğlu' ${ }^{1 *} \oplus$, Reşat Acar ${ }^{2}$ \\ ${ }^{1}$ Erzincan Binali Yıldırım Üniversitesi, Mühendislik Fakültesi, Inşaat Mühendisliği Bölümü, 24002, Erzincan. \\ ${ }^{2}$ Atatürk Üniversitesi, Mühendislik Fakültesi, Inşaat Mühendisliği Bölümü, 25240, Erzurum.

\section{Özet}

Kuraklık hidroelektrik enerji üretimi, sağlık, sanayi, turizm, ekonomi, tarım ve hayvancıllk gibi çeşitli sektörleri olumsuz etkileyen bir doğal afettir. Bu nedenle izlenmesi, zamansal ve mekânsal dağılımının belirlenmesi ve önlemler alınarak kuraklık risklerinin yönetilmesi büyük öneme sahiptir. Bu çalışmada, Fırat Havzası'ndaki çeşitli meteorolojik ve hidrolojik kuraklıkların Kriging, Radyal Tabanlı Fonksiyon (RTF) ve Ters Mesafe Ağırlıklandırma (TMA) enterpolasyon yöntemleri ile zamansal ve mekânsal değişimleri kuraklık sınıflarına göre renklendirilerek haritalandırması ve havzadaki kuraklık risk durumunun değerlendirilmesi amaçlanmıştır. Bunun için Fırat Havzası ve çevresinde bulunan 16 adet Meteoroloji Gözlem İstasyonu ve 18 adet Akım gözlem istasyonuna ait Standartlaştırılmış Yağış İndeksi, İstatistiksel Z-Skoru İndeksi, Yă̆ış Anomalisi İndeksi, Standardize Yağış Evapotranspirasyon Indeksi, Keșif Kuraklık Indeksi ve Standart Akım İndeksi değerleri kullanılmıştır. Analizler sonucunda havzada meteorolojik kuraklikların tahmininde Kriging metodu, hidrolojik kuraklıkların tahmininde ise RTF en etkili yöntemler olduğu tespit edilmistir. Havzanın kuraklık risk düzeyi yüksek tespit edildiği için çalışma alanında kuraklık yönetim planının yapılması, olumsuz kuraklık etkilerinin azaltılması, erken uyarı ve kuraklık önlemlerinin alınması önerilmektedir.

\section{Anahtar Sözcükler}

Kuraklık, Kuraklık İndeksi, Enterpolasyon, Kuraklık Haritası, Zamansal ve Mekânsal Analiz, Risk Analizi

\section{Determination of Meteorological and Hydrological Drought Maps with Various Interpolation Methods in the Euphrates Basin}

\begin{abstract}
Drought is a natural disaster that adversely affects various sectors such as hydroelectric power generation, health, industry, tourism, economy, agriculture and animal husbandry. For this reason, monitoring, determining the spatio-temporal distribution, and managing drought risks by taking precautions are of great importance. In this study, it is aimed to map the spatio-temporal changes of various meteorological and hydrological droughts in the Euphrates Basin according to drought classes with Kriging, Radial Based Function $(R B F)$ and Inverse Distance Weighting (IDW) interpolation methods and to evaluate the drought risk situation in the basin. For this, Standardized Precipitation Index, Statistical Z-Score Index, Precipitation Anomaly Index, Standardized Precipitation Evapotranspiration Index, Reconnaissance Drought Index and Standardized Runoff Index values were used for 16 Meteorology Observation Stations and 18 stream-gauging stations in the Euphrates Basin. As a result of the analyses, it has been determined that the Kriging method is the most effective method in predicting meteorological droughts in the basin, and RBF is the most effective method in predicting hydrological droughts. Since the drought risk level of the basin is determined to be high, it is recommended to make a drought management plan in the study area, to reduce negative drought effects, and to take early warnings and drought precautions.
\end{abstract}

$\underline{\text { Keywords }}$

Drought, Drought Index, Interpolation, Drought Map, Spatio-Temporal Analysis, Risk Analysis

\section{Giriş}

Sera gazlarının atmosferdeki salınımının hızla artması küresel ve bölgesel ölçekte iklimin daha sıcak ve değişken seyir izlemesine neden olmaktadır. Bu nedenle ekstrem (uç) hava ve iklim olaylarının karakteristiklerinde büyük değişimler meydana gelmekte ve meteoroloji tabanlı taşkın ve kuraklık gibi doğal afetlerin önemi giderek artmaktadır. Bu artış çeşitli kurumlar, bilim adamları ve çevrecileri kuraklığın neden olduğu sorunu hafifletmek için etkili yönetim politikaları geliştirme üzerine odaklanmasına neden olmuştur. Kuraklığın değerlendirilmesi ve tehlike haritalarının yapılması, bölgesel kuraklık özelliklerini anlamak ve etkili bir kuraklık yönetim planı oluşturmak için önemli bir rol oynamaktadır. Ayrıca, kuraklıkları izlenmesi ve tehlike haritalarını yapılması, kuraklık etkilerinin azaltılmasının temel basamağıdır (Rahman ve Lateh 2016). 
Kuraklık yıkıcı etkiler yaratabilen bir doğa olayıdır. Bu yıkıcı etkileri azaltabilmek için kuraklığın ne sıklıkta meydana geldiği ve hangi bölgelerde daha şiddetli görüldüğü belirlenmelidir (Gümüş 2017). Kuraklığa karşı önlem almak ve hazırlıklı olmak kuraklık karakteristiklerinin belirlenmesine bağlıdır (Mishra ve Nagarajan 2011). Ancak meteorolojik ve hidrolojik verileri yetersiz olması ekstrem kuraklık karakteristiklerinin belirlenmesinin önündeki en büyük engeldir (Anisfeld 2011). Kuraklığın etki alanı, şiddeti, süresi ve frekansı gibi bilgiler, kuraklık izleme aracı olarak kullanılan kuraklık indeksleri yardımıyla belirlenebilmektedir. Bu bilgiler analistlere ve karar vericilere kuraklığın karakteri hakkında fikir vererek kuraklık risk yönetimi ve kuraklık eylem planının oluşturulmasında kullanılmaktadır. Kuraklıkların izlenmesi ve tahmin edilmesi, kuraklık önlemleri için zaman kazandırmakta ve kuraklığın olumsuz etkilerini azaltmasına yardımcı olmaktadır.

Kuraklıkların takip edilmesi ve kuraklık karakteristiklerinin belirlenmesi için kuraklık indeksleri yaygın bir şekilde kullanılmaktadır. Meteorolojik ve hidrolojik kuraklık indeksleri ile ilgili birçok çalışma yapılmıştır. Bunlardan öne çıkanları şu şekildedir; Morid vd. (2006) çalışmalarında, İran'ın Tahran eyaletinde yedi kuraklık indekslerini (Desiles indeksi (Dİ), Normal Yüzdesi İndeksi (NYİ), Çin-Z indeksi (CZI), Modifiye Edilmiş Çin Z İndeksi (MÇZİ), Standart Yağıș İndeksi (SYİ) Z-Skoru ve Efektif Kuraklık İndeksi (EKİ)) değerlendirmişler ve performanslarını karşılaştırmışlardır. Gümüş (2017) çalışmasında, 3, 6 ve 12 aylık Akım Kuraklık İndeksi (AKİ) değerlerini kullanarak Asi havzasındaki hidrolojik kuraklıkların analizini yapılmıştır. AKİ değerleri ile kurak ve nemli dönemlerinin şiddeti, büyüklüğü ve dağılımı tespit edilmiştir. Gümüş vd. (2018) Fırat Havzasında bulunan E21A002 numaralı istasyonda AKİ değerleri aracılığıyla zamansal kuraklık değerlendirmesi yapmışlardır. Li vd. (2019) Yangtze Nehri Havzasından alınan aylık meteorolojik veriler kullanılarak SYİ ve SYEI değerlerine göre kuraklık olaylarının çeşitli özelliklerini analiz etmişlerdir. Wable vd. (2019) çalışmalarında, Normal Yüzdesi İndeksi (NYİ), Standart Yağış İndeksi (SYİ), Standart Yağış evapotranspirasyon İndeksi (SYİ), Efektif Kuraklık İndeksi (EKİ) ve Keşif Kuraklık İndeksi (KKİ) değerlerinin göreceli kuraklık sıklığı indeksine göre performansları değerlendirilmiştir. Karabulut (2020) Standart Yağış İndeksi (SYİ) ve kümülatif sapma eğrisi aracılığıyla Sivas ilindeki kuraklık koşullarını değerlendirmiştir.

Kuraklıkların çeşitli enterpolasyon metotları kullanılarak zamansal ve mekânsal dağılımın belirlenmesi üzerine literatürde birçok çalışma bulunmaktadır. Bunlardan öne çıkanları şu şekildedir; Ali vd. (2011) araştırmasında, Normal Kriging (NK), Ters Mesafe Ağırlıklandırma (TMA) ve İnce Plaka Pürüzsüz Eğri (Thin Palte Smoothing Spline) olmak üzere çeşitli jeoistatistik yöntemler kullanarak kuraklık haritaları üretilmişlerdir. Buttafuoco vd. (2015); Manikandan ve Tamilmani (2015); Rahman ve Lateh (2016); Mahajan ve Dodamani (2016) çalışmalarında, Standart Yağış İndeksi'ni (SYİ) kullanarak, meteorolojik kuraklıkların mekânsal ve zamansal değişimini araştırmayı amaçlamışlardır. Afzali vd. (2016) araştırmasında, kuraklık haritalarının üretilmesi için Normal (Ordinary) Kriging (NK), İndikatör (İndicator) Kriging (İK), Rezidüel (Residual) Kriging (RK), Olasılık (Probabilty) Kriging (OK), Basit (Simple) Kriging (BK), Evrensel (Universal) Kriging (EK) ve Ters Mesafe Ağırlıklandırma (TMA) yöntemlerini kullanılmıştır. Yuan vd. (2016) çalışmasında, kuraklık indeksi, mevsimsellik, istasyon yoğunluğu, enterposyon metodu ve iklim bölgesinin doğru kuraklık haritası elde etmedeki etkisini araştırmışlardır. Nasrollahi vd. (2018) çalışmasında, 3 ve 12 aylık zaman periyotlarında Standart Yağış İndeksi (SYİ), Kriging Enterpolasyonu ve Doğal Kırılma Yöntemleri (Natural Break Method) kullanılarak Kuraklık Tehlike İndeksi (Drought Hazard İndex-KTİ) haritası elde edilmiştir. Boustani ve Ulke (2020) çalışmasında, Normal Yağış Yüzdesi (NYY), Yağış Kuyrukları İndeksi (YKİ), Yağış Anomali İndeksi (YAİ), ZSkoru İndeksi (ZSI), Çin Z İndeksi (ÇZI), Modifiye Edilmiş Çin Z İndeksi (MÇZİ), Standart Yağış İndeksi (SYI) ve Erinç İndeksi (Eİ) kullanılarak kuraklık durumu incelenmiştir. Kullanılan indekslerden havzaya en uygun zaman dilimi ile indeks değeri seçilerek havzada kuraklık haritaları oluşturulmuştur. Özcan (2020) çalışmasında, Dicle Havzası'nda bulunan 16 akım gözlem istasyonuna ait aylık ortalama akım değerleri kullanılarak havzaya ait hidrolojik kuraklıklar akım kuraklık indeksi (AKİ) yöntemi ile belirlemiştir. Kuraklıkların mekânsal dağılımlarının belirlenmesi için ise ters mesafe ağırlıklı enterpolasyon yönteminden faydalanılmıştır.

Hükümetler Arası İklim Değişikliği Paneli (IPCC) raporlarına göre, Akdeniz havzasında bulunan Türkiye iklim değişikliğinden en fazla etkilenen ülkeler arasında bulunmaktadır (IPCC 2007). Bu nedenle günümüzde kuraklık meydana geldikten sonra uygulanan kriz yönetimi yerine görülmesi muhtemel kuraklıkların etkilerini azaltılması için kullanılan risk yönetimi yaklaşımı uygulanmalıdır. Bu yaklaşım, su kaynaklarının kullanımı ve yönetilmesi, kuraklıkların takip edilmesi, kuraklıkların zamansal ve mekânsal dağılımın belirlenmesi ve kuraklık risklerinin haritalanmasına dayanmaktadır.

Yapılan bu çalışmada, kuraklıkların belirlenmesi ve izlenmesi yaygın olarak kullanılan, güvenilirliği daha önceki çalışmalar ile kanıtlanmış 5 farklı meteorolojik kuraklık indeksi (Standardize Yağış İndeksi (SYİ), Z-Skoru İndeksi (ZSI), Yağış Anomali İndeksi (YAİ), Keşif Kuraklık İndeksi (KKI), Standart Yağış Evapotranspirasyon İndeksi (SYEİ)) ve tek bir hidrolojik kuraklık indeksi (Standardize Akım İndeksi-SAİ) ile yapılmıştır. Bu göstergelerin seçilmesinde, indeks formüllerinin standartlaştırmaya dayalı olması ve kuraklık sınıflandırma kriterlerinin benzer olması etkili olmuştur. Çalışmada en şiddetli kuraklıkların görüldüğü yıllar gidişler analizi ile belirlenerek seçilen kuraklık indeksleri ile meteorolojik ve hidrolojik kuraklıkların zamansal ve mekânsal dağılımı belirlenmiştir. Çalışmada Kriging, Radyal Tabanlı Fonksiyon (RTF) ve Ters Mesafe Ağırlıklandırma (TMA) enterpolasyon metotlarının performanslarının karşılaştırması, zamansal ve mekânsal kuraklık haritalarının elde edilmesi ve kuraklık açısından riskli bölgeler tespit edilerek yönetilmesini amaçlanmaktadır. 


\section{Materyal ve Yöntem}

\section{1. Çalışma Alanı ve Veriler}

Fırat Nehri’nin ortalama yıllık akımı yaklaşık olarak 32 milyar metreküp olup bu miktarın \%80’i Keban Barajı'nın kuzeyindeki yukarı havzada yer almaktadır. Nisan ve mayıs aylarındaki maksimum akım toplam yıllık akımın \%42'sine denk gelmektedir. Fırat Nehri havzasında akım değerleri değişkenlik göstermektedir. Kış aylarında yağışın kar şeklinde

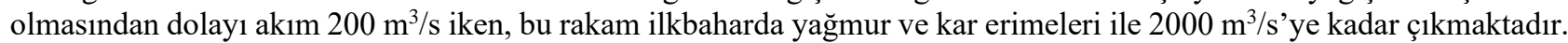
Temmuz ayında hızla azalan akım eylül-ekim aylarında en az seviyeye inmektedir (Yıldırım 2006).

Güneybatı Asya'nın en uzun nehri olan Fırat Nehri’nin 1236 km’si Türkiye sınırları içerisinde olmak üzere toplam uzunluğu 2700 km'dir (Aytemiz ve Kodaman 2006). Fırat nehrinin en önemli kolları; Murat, Karasu, Tohma, Peri, Çaltı ve Munzur'dur. Firat Nehri üzerinde kurulmuş olan büyük barajlar sırasıyla Keban, Karakaya, Atatürk, Birecik ve Karkamış barajlarıdır. Bu barajların büyük haznelere sahip olması, bu bölgede su kaynakları yönetimi ve planlamasının önemini artırmaktadır.

Hazırlanan çalışmada, Fırat Havzası'nda ve havzaya yakın olan sürekli ve en az 30 yıllık veriye sahip (1966 ile 2017 yılları arası) olan 16 adet yağış gözlem istasyonu seçilmiştir. Çalışmada kullanılan yağış ve sıcaklık verileri Meteoroloji Genel Müdürlüğü'nden temin edilmiştir. Çalışmada kullanılan meteoroloji gözlem istasyonlarına ait konum haritası ise Şekil 1'de gösterilmiştir.

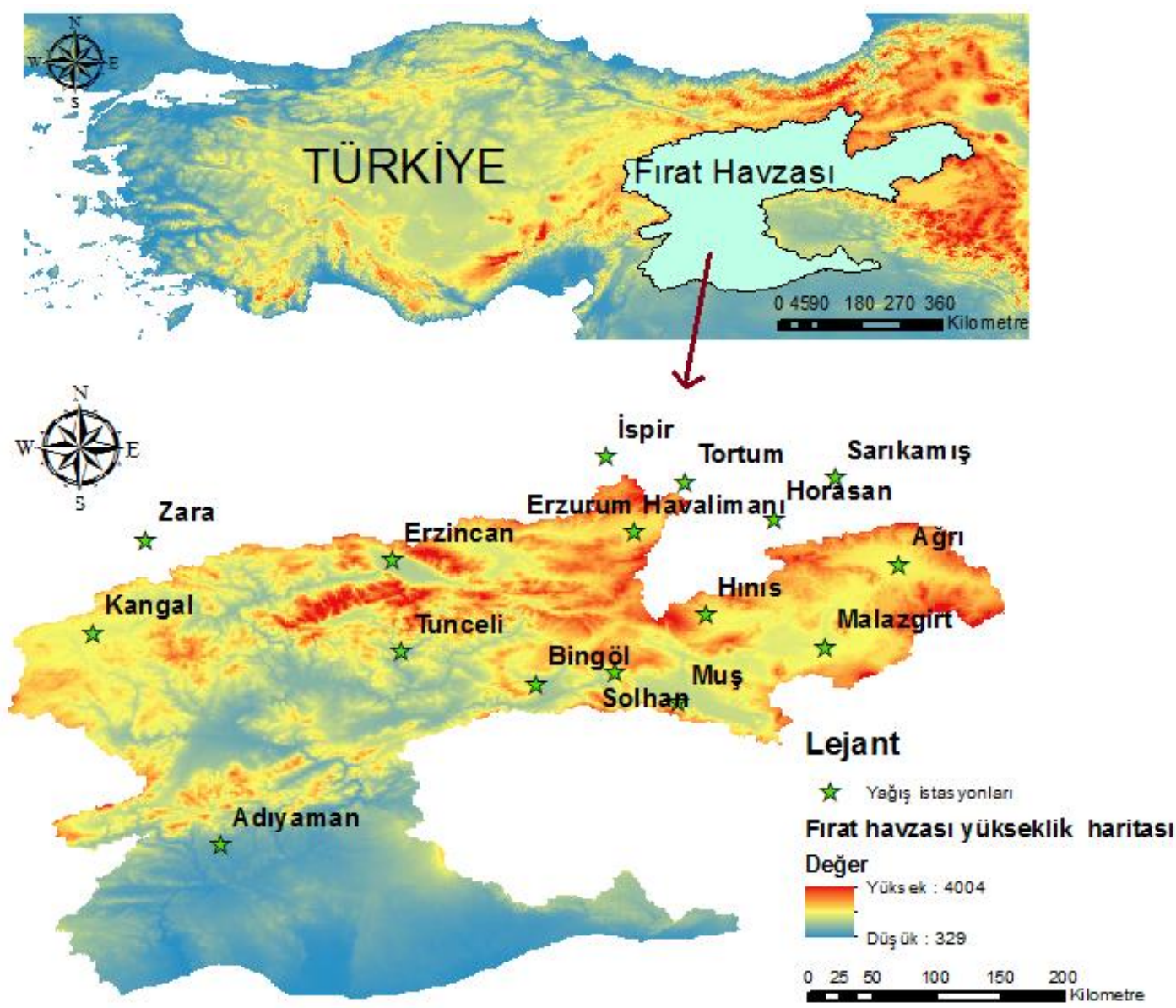

Şekil 1: Çalışmada kullanılan meteoroloji gözlem istasyonlarına ait konum haritası

Çalışmada kullanılan akım verileri Devlet Su İşleri (DSİ) Genel Müdürlüğü tarafından düzenlenen akım gözlem yıllıklarından alınmıştır. Bu veriler Fırat Havzası ve yakınındaki istasyonlardan seçilen eksiksiz en uzun dönem olan 1970 ile 2009 yılları arasını (40 yıl) kapsamaktadır. Çalışmada kullanılan akım gözlem istasyonlarına ait konum haritası ise Şekil 2'de gösterilmiştir. Çalışmada kullanılan verilere ait bazı değerler Ek-1 ve Ek-2'de verilmiştir. 


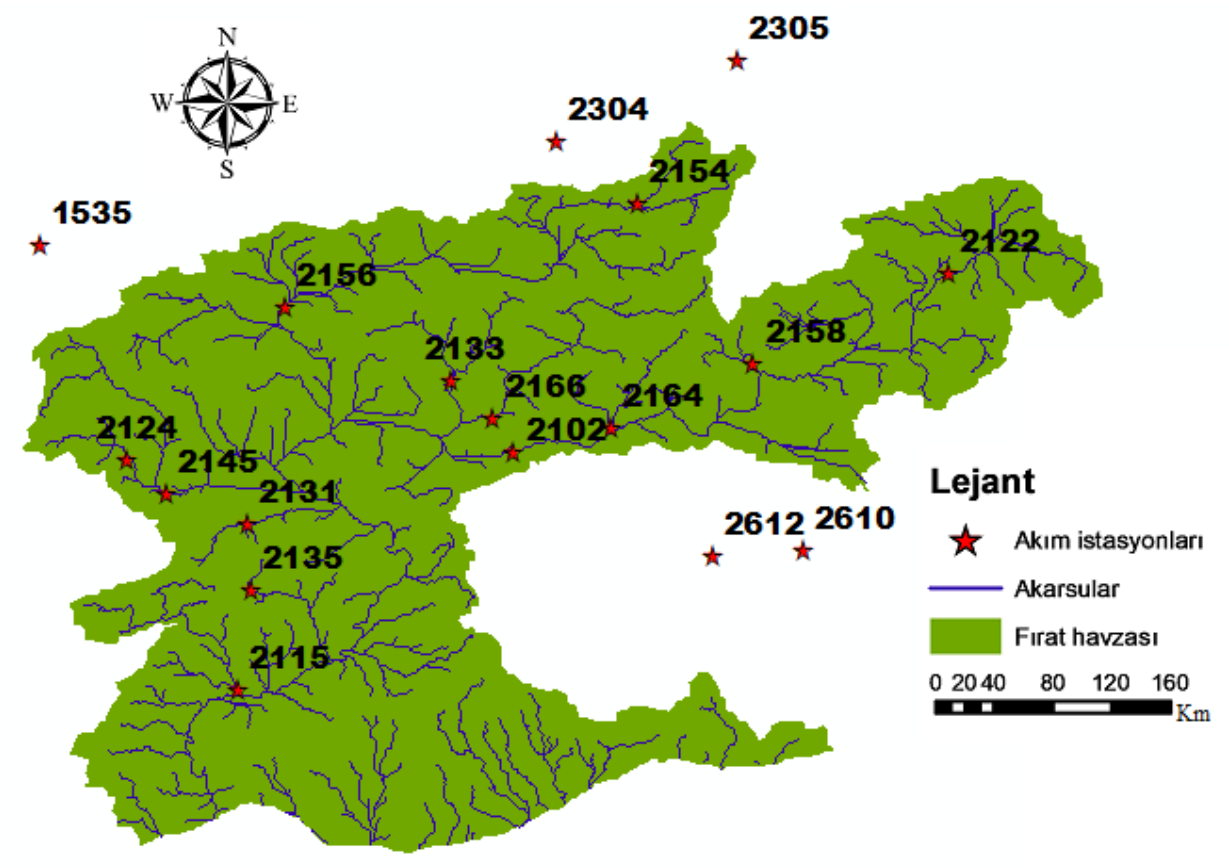

Şekil 2: Çalışmada kullanılan akım gözlem istasyonlarına ait konum haritası

\subsection{Kuraklık İndeksleri}

Kuraklık indeksleri, kuraklık durumunu tespit etmek ve izlemek, kuraklık tepkilerinin zamanlamasını ve seviyesini belirlemek, kuraklık olaylarını karakterize etmek, kuraklık şiddeti düzeylerini kuraklık tepkileri ile birleştirerek kuraklık yönetim planının yapılmasında kullanıldığı için büyük öneme sahiptir (Wilhite 2005). Bu çalışmada kuraklıkların belirlenmesi ve karşılaş̧ırılabilmesi için standartlaştırılmış indeksler seçilmiştir. Bu indeksler: Standart Yağış İndeksi (SYI), Standart Yağış ve Evapotranspirasyon İndeksi (SYEI), Z-Skoru İndeksi (ZSİ), Keşif Kuraklık İndeksi (KKI), Standart Akış İndeksi (SAİ) şeklindedir.

\subsubsection{Standart yağış indeksi (SYi)}

SYİ'nin temeli yağış verisinin normalleştirme işlemidir. SYİ değerinin hesaplanması temel olarak aşağıdaki adımları içerir: (1) yağış zaman serisi üretir; (2) Yağışlara uyacak bir frekans dağılımı seçilir ve uydurulan frekans dağılımından kümülatif dağılım oluşturulur; (3) SYİ değerini elde etmek için kümülatif olasılıklar ortalaması 0 standart sapması 1 olan standart normal dağılıma dönüştürülür (McKee vd. 1993).

\subsubsection{Standart yağış ve evapotranspirasyon indeksi (SYEi)}

SYİ'deki eksiklikleri gidermek amacıyla Vicente-Serrano vd. (2010) tarafindan ortaya atılan bu indeks iklimdeki ısınma etkilerini de hesaba katabilmektedir. SYEİ'nin hesaplanması, SYİ'de kullanılan yağışlara ek olarak potansiyel evapotranspirasyon (PET) değerlerini de hesaba katmaktadır. Bu indeks değerleri, yağış ile PET değerlerinin farkına 3 parametreli log-lojistik dağılımın uydurulması ile elde edilmektedir.

\subsubsection{Z-Skoru indeksi (ZSi)}

ZSİ, popülasyon ortalamasını tek bir yağış değerinden çıkarılması ile elde edilen fark değerini popülasyon standart sapmasına bölünmesi ile elde edilen boyutsuz bir katsayıdır. Bu dönüştürme işlemine standartlaştırma denir. Z-skoru, bir yağış değerinin ortalamanın üzerinde veya altında kaç standart sapma olduğunu gösterir.

\subsubsection{Keşif kuraklık indeksi (KKi)}

KKİ, kuraklık değerlendirmesi için genel bir meteorolojik indeks olarak tanımlanmıştır. Bu indeks kurak ve yarı kurak bölgelere büyük ölçüde kabul görmektedir. KKİ, aylık, mevsimlik ve yıllık bazda yağış değerlerinin potansiyel evapotranspirasyona oranından elde edilebilmektedir (Tsakiris ve Vangelis 2005). 


\subsubsection{Yağış anomali indeksi (YAi)}

YAİ, Van Rooy (1965) tarafından bulunan bu indeks yağışın normal değerinden sapmasını hesaplanmaktadır.

\subsubsection{Standart akış indeksi (SAi)}

SAİ, hidrolojik akış yüzdesi ile ilişkili birim standart normal sapma olarak ifade edilir. Shukla ve Wood (2008) tarafından geliştirilen bu indeks hidrolojik kuraklıkların belirlenmesinde kullanılmaktadır. Tablo 1'de çalışmada kullanılan kuraklık indekslerine ait kuraklık sınıflandırması verilmiştir.

Tablo 1: Kuraklık indekslerine ait kuraklık sınıflandırılması

\begin{tabular}{ccc}
\hline SYİ-SYEİ-ZSİ-KKİ-SAİ & YAI & Kategori \\
\hline İndeks $\geq 0$ & İndeks $\geq 0$ & Sulak dönem \\
$-1<$ İndeks $\leq 0$ & $-1,2<$ İndeks $\leq 0$ & Hafif kurak \\
$-1,5<$ İndeks $\leq-1,0$ & $-2,1<$ İndeks $\leq-1,2$ & Orta düzey kurak \\
$-2<$ İndeks $\leq-1,5$ & $-3<$ İndeks $\leq-2,1$ & Şiddetli kurak \\
İndeks $\leq-2,0$ & İndeks $\leq-3$ & Olağanüstü kurak \\
\hline
\end{tabular}

\subsection{Gidişler (Runs) analizi}

Bir $\mathrm{X}_{\mathrm{j}}$ rastgele değişkeninin, herhangi bir $\mathrm{X}_{\mathrm{j}}(\mathrm{t})$ stokastik süreci içerisinde, bir $\Delta \mathrm{t}$ zaman aralığı içerindeki durumunu göz önüne alalım. Burada $X_{0}$, kesim seviyesini ve $X_{j}$ ise yağış serisini göstersin. $X_{j}$ değişkeninin verilen bir $X_{0}$ değerinin altında kaldığı süre negatif gidiş uzunluğu (ya da kısaca gidiş uzunluğu: $N^{-}$) üzerinde kaldığı süre ise (pozitif gidiş uzunluğu: $\mathrm{N}^{+}$) olarak tanımlanır. Gidiş uzunluğu verilen $\mathrm{x}_{0}$ düzeyindeki kuraklığın süresini belirler. $\mathrm{X}_{\mathrm{j}}>\mathrm{X}_{0}$ olması durumu sulak dönemi, $\mathrm{X}_{\mathrm{j}}<\mathrm{X}_{0}$ olması durumu ise kurak dönemi ifade etmektedir. Kurak devre boyunca yağış miktarı ile $\mathrm{X}_{0}$ değeri farkına ise gidiş toplamı denir. Gidiş toplamı göz önüne alınan kuraklığın şiddetini ifade eder ve Denklem 1'deki gibi hesaplanır.

$\mathrm{D}_{\mathrm{j}}=\sum_{\mathrm{j}=1}^{\mathrm{m}}\left(\mathrm{X}_{0}-\mathrm{X}_{\mathrm{j}}\right)$

$\mathrm{X}_{0}$ çalışmanın amacına göre seçilen kesim seviyesidir. Bu çalışma için kritik kuraklık kesim seviyeleri $-2,-1,5,-1$ ve 0 olarak seçilmiştir.

\subsection{Kuraklık Enterpolasyonu}

Kuraklık indekslerinin zamansal ve mekânsal analizi kuraklık risk durumunu değerlendirilmesi açısından büyük öneme sahiptir. Kuraklık indeks değerleri yağış, sıcaklık, potansiyel evapotransprasyon (PET) gibi meteorolojik ve akım gibi hidrolojik parametrelere bağlıdır. Meteorolojik ve hidrolojik verilerin bir alandaki tüm noktalardan ölçülmesi hem maliyet açısından hem de teknik olarak mümkün olmamaktadır. Bunun için, kuraklıkların çeșitli zaman aralıklarında mekânsal dağılımını belirlemek için enterpolasyon metotları kullanılarak tüm yüzeydeki kuraklık değerleri tahmin edilmelidir. Böylece daha önce ölçülen verilerden faydalanılarak başka noktalardaki kuraklık değerleri tahmin edilebilmektedir. Bu çalışmada, mekânsal kuraklık enterpolasyonu için Arcmap 10.5 yazılımın Jeoistatistik Analiz Aracından faydalanılmıştır.

Bu çalışmada, kuraklık haritalarının oluşturulmasında, deterministik Ters Mesafe Ağırlıklı Enterpolasyon (TMAE), Radyal Tabanlı Fonksiyon (RTF) ve jeoistatistiksel Kriging yöntemi kullanılmıştır. Bu yöntemler, literatürde meteorolojik değişkenlerin (yağış, sıcaklık, buharlaşma) ve kuraklık şiddetlerinin haritalanmasında en çok tercih edilen ve birçok araştırmacı tarafından önerilen enterpolasyon teknikleri olduğu için seçilmiştir (Ali vd. 2011; Amini vd. 2019; Katipoğlu vd. 2021)

\subsubsection{Ters mesafe ağırlıklandırma yöntemi (TMAY)}

Ters Mesafe Ağırlıklı enterpolasyon, birbirine yakın olan noktaların birbirinden uzak olanlardan daha benzer olduğu varsayımını uygulayan yöntemdir. Ölçülmemiş herhangi bir noktanın değerini tahmin etmek için tahmin noktasının çevreleyen bilinen değerleri kullanmaktadır. Tahmin noktasına en yakın olan değerler, daha uzak olanlardan daha fazla etkiye sahip olacaktır. Böylece, ölçülen her noktanın mesafe ile azalan yerel bir etkiye sahip olduğunu varsayar (Johnston vd. 2001). 


\subsubsection{Radyal tabanlı fonksiyonlar (RTF)}

$\mathrm{Bu}$ çalışmada RTF yöntemleri olarak beş farklı enterpolasyon yöntemi kullanılmıştır. Bunlar; İnce Plaka Eğri, Gerilimli Eğri, Tamamen Düzenlenmiş Eğri, Çoklu ikinci Dereceli Fonksiyon ve Ters Çoklu ikinci Dereceli Fonksiyon yöntemleridir. "Her bir yöntem farklı sonuçlar ve farklı şekilde yüzeyler üretir. Bu yöntemlerin temeli, bilinen her noktadan çalışma alanı boyunca, noktaların incelenen değerlerine göre esnek bir yüzey geçirmektir (Johnston vd. 2001). RTF yöntemleri ile kullanılan örnek noktalarının konumları için yapılan tahminler ile gerçek değerleri aynıdır yani tam enterpolasyon yöntemleridir. Ancak örnek noktalarının konumları dışındaki noktalar için yapılan tahminler, gerçek değerlerin minimum değerinin altında, maksimum değerinin üstünde olabilir" (Johnston vd. 2001). Tamamen Düzenlenmiş Eğri yöntemi, hızlı değişen varyasyonlar için gerçekte olduğundan daha yumuşak yüzeyler üretebilir. Tamamen Düzenlenmiş Eğri yöntemine göre Gerilimli Eğri yöntemi, daha düz ve pürüzlü bir yüzey oluşturur. İnce Plaka Eğri yöntemi, diğer yöntemler sonucunda ortaya çıkan aşırı değerlerin aksine yerel olarak bir yumuşatma ortalaması kullanarak daha pürüzsüz yüzeyler oluşturur (Lilly 2016). Çoklu ikinci Dereceli Fonksiyon yöntemi, Ronald Hardy tarafından 1968 yılında topoğrafik haritalar oluşturmak üzere tasarlanmıştır. Bu yöntem konumsal olarak dağınık şekilde yayılmış noktalar ile uygun sonuçlar üretmektedir. Ters Çoklu ikinci Dereceli Fonksiyon yöntemi veri değerlerine bağımlıdır (Chenoweth ve Sarra 2009).

\subsubsection{Kriging}

Kriging, bilinmeyen noktaların, belirli bir yarıçap içindeki bilinen noktaların ağırlıklı toplamı ile tahmin edilmesine dayanan istatistiksel bir metottur (Bajjali 2017). Kriging, gelişmiş bir tahmin yüzeyi modellemesi için kullanılır ve aynı zamanda hatalar veya tahmin belirsizliğini de hesaba katar (Bajjali 2017). Kriging, TMAE'ye benzer çünkü her bir konum için bir tahmin değeri elde edilirken çevredeki ölçüm ağırlıklarından yararlanır. Bununla birlikte, ağırlıklar sadece ölçülen noktalar ile tahmin yeri arasındaki mesafeye değil, aynı zamanda ölçülen noktalar arasındaki genel mekânsal düzenlemeye de dayanmaktadır. Mekânsal düzenlemeyi ağırlıklarda kullanmak için, mekânsal otokorelasyon ölçülür. Doğal fiziksel olaylar (yağış, sıcaklık, toprak özellikleri vb.) genelde alansal otokorelasyona sahiptir. Yani birbirine yakın mesafede olan örnekleme noktalarının benzer değere sahip olduğu ve birbirinden uzak mesafede olan örneklerin arasındaki değer farkının ise büyük olduğu varsayımı ile bu otokorelasyon belirlenir. Bu otokorelasyon Kriging gibi yöntemlerde sorgulanabilir ve belirgin bir model ile hesaplanabilirken, TMA gibi yöntemlerde açık ve belirgin bir otokorelasyon hesabı yoktur ve sadece mesafeye göre ağırlıklandırma katsayısı ile belirlenmeye çalışılır.

\subsection{Kuraklık Haritalarının Oluşturulması}

Noktasal olarak referanslandırılmış verilerin alansal olarak ifade edilmesi için kullanılan enterpolasyon metodunda, model parametreleri ve noktaların dağılımının büyük etkisi bulunmaktadır. Bu çalışmada, Kriging, RTF ve TMA yöntemleri ve yöntemlere ait parametrelerin çeşitli varyasyonları denenerek en uygun meteorolojik ve hidrolojik kuraklık haritalarının belirlenmesi amaçlanmıştır. Elde edilen kuraklık haritaları ile havzada görülen kuraklık şiddetleri ve sınıflarının dağılımı belirlenerek kuraklık yönetim planı çerçevesinde kuraklık riski olan bölgeler ortaya çıkarılmıştır. Küresel ısınma ve iklim değişikliği etkileri de hesaba katıldığında şiddetli kuraklık görülen bölgelerde gelecekte olası kuraklık felaketi için kuraklık hazırlıklarının yapılmasına katkıda bulunmaktadır.

Kriging modeli çeşitli model parametreleri Tablo 2'de verilmiştir. Bu parametreler arasından en uygununu belirlemek için çeşitli varyasyonlar denenerek en küçük hata kareler ortalamasının karekökü (HKOK) değerini veren kriging modeli uygulanmıştır. HKOK değerinin sıfıra yakın olması tahmin edilen değerlerin gerçeğe yakın olduğunu göstermektedir. Bu çalışmada, en küçük HKOK değerine sahip model kullanılarak kuraklık tehlike haritaları çizilmiştir. HKOK değeri, model tahminlerinin ölçüm değerlerine olan yakınlığını gösteren indikatördür ve bu değer tahmin hatasını vermektedir. 
Tablo 2: Ordinary Kriging model seçenekleri

\begin{tabular}{|c|c|c|}
\hline Yarivariogram Modeli & Kernel Fonksiyonu & Komşuluk ve Sektör Tipi \\
\hline Dairesel (Circular) & Eksponansiyel (Exponential) & Pürüzsüz Komşuluk \\
\hline Küresel (Spherical) & Polinominal (Polynominal) & Standart Komşuluk \\
\hline Dörtlü küresel (Tetraspherical) & Normal (Gaussian) & 1 daire dilimi \\
\hline Beşli küresel (Pentaspherical) & Epanechnikov & 4 daire dilimi \\
\hline Eksponansiyel (Exponential) & İkinci dereceden (Quartic) & 45 derecelik 4 daire dilimi \\
\hline Normal (Gaussian) & Sabit (Stable) & 8 daire dilimi \\
\hline $\begin{array}{c}\text { Rasyonel kuadratik } \\
\text { (Rational Quadratic) }\end{array}$ & & \\
\hline Boşluk etkisi (Hole Effect) & & \\
\hline K-Bessel & & \\
\hline J-Bessel & & \\
\hline Sabit (Stable) & & \\
\hline
\end{tabular}

$\mathrm{Bu}$ çalışmada, Radyal tabanlı fonksiyon enterpolasyonunun uygulanmasında, Kernel fonksiyonları, komşuluk ve sektör tipleri deneme yanılma yolu ile seçilerek çapraz değerleme yöntemi ile en küçük HKOK değerini veren model uygulanmıştır. Radyal tabanlı fonksiyona ait model seçenekleri Tablo 3'de sunulmuştur. TMA yöntemine ait komşuluk ve sektör tipleri ise RTF ile aynı olmaktadır.

Tablo 3: RTF model seçenekleri

\begin{tabular}{|c|c|c|}
\hline Kernel Fonksiyonu & Sektör Tipi & Komşuluk \\
\hline $\begin{array}{c}\text { Tamamen Düzenlenmiş Eğri } \\
\text { (Completely regularized spline) }\end{array}$ & 1 daire dilimi & Standart \\
\hline $\begin{array}{c}\text { Gerilimli Eğri } \\
\text { (Spline with tension) }\end{array}$ & 4 daire dilimi & Yumuşak \\
\hline $\begin{array}{c}\text { Çoklu ikinci Dereceli Fonksiyon } \\
\text { (Multiquadric function) }\end{array}$ & 45 derecelik 4 daire dilimi & \\
\hline $\begin{array}{c}\text { Ters Çoklu ikinci Dereceli Fonksiyon } \\
\text { (Inverse multiquadric function) }\end{array}$ & 8 daire dilimi & \\
\hline İnce-Plaka Eğri (Thin-plate spline) & & \\
\hline
\end{tabular}

Kuraklığın olumsuz etkilerinin azaltılması ve önceden tahmin edilebilmesi için, kuraklık şiddetinin zamansal ve mekânsal yayılımı belirlenmelidir. Bu nedenle, en uygun kuraklık indekslerinin çeşitli enterpolasyon yöntemleri kullanılarak havza bazında kuraklık haritalarının oluşturulması gerekmektedir. Kuraklık haritalarının tahmin edilmesinde en çok tercih edilen enterpolasyon metotları Kriging, Radyal Tabanlı Fonksiyon (RTF) ve Ters Mesafe Ağırlıklandırma (TMA) yöntemidir. Bu yöntemlerden en etkili olanı ise çapraz geçerlilik testi ile elde edilen çeşitli istatistiksel parametreler karşılaştırılarak belirlenebilmektedir (Ali vd. 2011; Rahman ve Lateh 2016; Yuan vd. 2016).

\section{6. Çapraz Geçerlilik (Cross validation)}

Çapraz geçerlilik, yarıvariogram model parametrelerin tahmin edilmesi amacıyla kullanılan etkili bir metottur. Bu metot, örnek veri setindeki bilgileri kullanarak, tahmin edilen ve gerçek değerleri (istasyon ölçüm değerleri) arasındaki ilişkiyi inceler. Bu metotta, bir lokasyondaki değer, veri setinden geçici olarak çıkarılır ve geriye kalan diğer değerler kullanılarak çıkartılan bu lokasyon için tahmin yapılır. Bu işlem aynı şekilde geride kalan tüm örnekler için tekrarlanır (Isaaks ve Srivastava 1989) Örneğin, aşağıdaki Şekil 3'de 10 rastgele dağıtılmış veri noktasını gösterilmektedir. Çapraz değerleme bir noktayı (kırmızı nokta) atlar ve kalan dokuz noktayı (mavi noktalar) kullanarak bu konumun değerini hesaplar. Atlanan noktanın konumundaki öngörülen ve gerçek değerler karşılaştırılır. Bu prosedür ikinci bir nokta için tekrarlanır ve bu böyle devam eder (Johnston vd.2001). Böylece gözlemlenen değerler tahmin edilir ve gerçek değerler ile aradaki fark1 (hata değeri) tespit edilir. Tahmin edilen haritaların doğruluğu sınanırken çeşitli hata kriterleri kullanılabilmektedir. Bu çalışmada, tahmin edilen haritaların değerlendirilmesinde HKOK değerleri karşılaştırması ile yapılmıştır. 


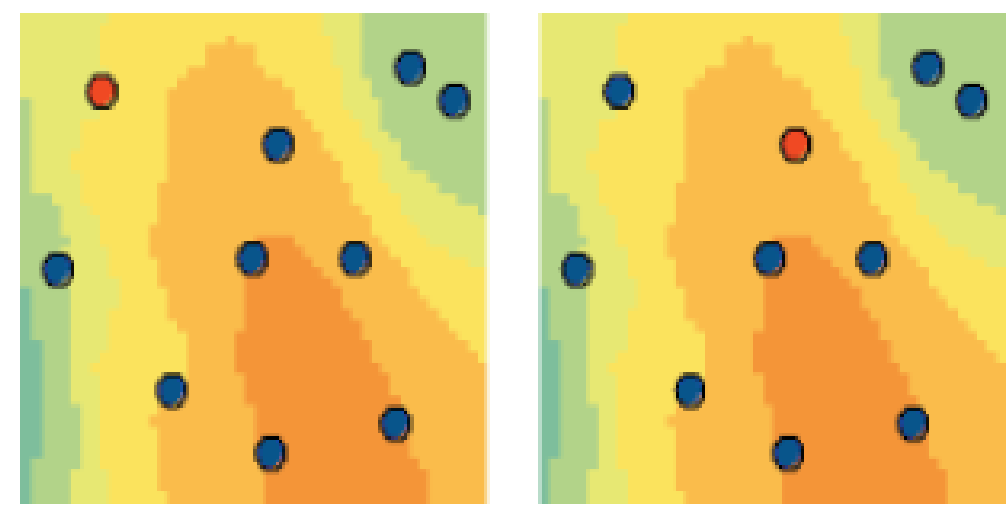

Şekil 3: Çapraz geçerlilik metodu (URL-1 2020)

\subsection{Modellerin Değerlendirilmesi}

Modeller hazırlandıktan sonra performansları istatistiksel doğruluk sınamasında kullanılan bir kriter olan hata kareler ortalamasının karekökü (HKOK) yardımıyla karşılaştırılmıştır. HKOK, tahmin edilen değerler ile gözlenen değerler arasındaki farkların belirlenmesi ile tahmin doğruluğunu ölçen istatistiksel ölçüt olup Denklem 2 ile hesaplanmaktadır.

$\mathrm{HKOK}=\sqrt{\frac{1}{\mathrm{~N}} \sum_{\mathrm{i}=1}^{\mathrm{N}}\left(\mathrm{x}_{\mathrm{i}}-\mathrm{y}_{\mathrm{i}}\right)^{2}}$

$\mathrm{Bu}$ denklemlerde; $\mathrm{x}_{\mathrm{i}}$ modellere ait beklenen (gözlenen) değerleri, $\mathrm{y}_{\mathrm{i}}$ modellerin ürettiği çıktıları, $\mathrm{x}_{\mathrm{i}}-\mathrm{y}_{\mathrm{i}}$ değeri hata (kalıntı) terimlerini ve $\mathrm{N}$ veri adedini simgelemektedir. Hata oranları en küçük (0'a yakın) olan model en iyi olarak değerlendirilmektedir.

\section{Bulgular ve Tartışma}

Hesaplanan kuraklık indeksi değerlerine göre en kurak tarihler için Fırat Havzası kuraklık haritaları oluşturulmuştur. Çalışma alanındaki istasyonların noktasal kuraklık değerleri enterpolasyon yöntemi ile alan üzerinde yayılımı kuraklık sınıflarına göre renklendirilerek kuraklık tehlikesi haritalandırılmıştır.

Fırat Havzası'nın çeşitli kuraklık indekslerine ait ekstrem meteorolojik kuraklık karakteristikleri Tablo 4'te gösterilmiştir. Bu çalışmada kullanılan kuraklık indekslerinin hesaplanması ve değerlendirilmesi hakkında detaylı bilgi Katipoğlu vd. (2020) çalışmasında verilmiştir.

Tablo 41: Fırat Havzası'nda görülen maksimum kuraklık karakteristiklerinin karşılaştırılması (Katipoğlu vd. 2021)

\begin{tabular}{|c|c|c|c|c|c|c|c|}
\hline İndeks & İstasyon & $\begin{array}{c}\text { Zaman } \\
\text { Periyodu } \\
\end{array}$ & $\begin{array}{c}\text { Kuraklık } \\
\text { Sayıs1 } \\
\end{array}$ & Başlangıç & Bitiş & Süre (Ay) & Şiddet \\
\hline \multirow{3}{*}{$\bar{\pi}$} & İspir & Aylik & 142 & 2013 Mart & 2014 Mart & 13 & $-19,05$ \\
\hline & Sarıkamış & 3 Aylık & 72 & 2011 Ekim & 2014 Ağustos & 35 & $-47,15$ \\
\hline & Sarıkamış & 12 Aylik & 33 & 2012 Nisan & 2017 Aralık & 69 & $-114,58$ \\
\hline \multirow{3}{*}{ 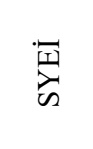 } & İspir & Aylık & 137 & 2013 Mart & 2014 Ağustos & 18 & $-21,37$ \\
\hline & Sarıkamış & 3 Aylık & 72 & 2011 Ekim & 2016 Mayıs & 56 & $-79,16 *$ \\
\hline & Sarıkamış & 12 Aylık & 26 & 2012 Nisan & 2017 Aralık & 69 & $-109,69$ \\
\hline \multirow{3}{*}{$\overline{\tilde{N}}$} & İspir & Aylık & 137 & 2013 Mart & 2014 Nisan & 14 & $-15,77$ \\
\hline & Sarıkamış & 3 Aylık & 71 & 2011 Ekim & 2014 Ağustos & 35 & $-45,12$ \\
\hline & Sarıkamış & 12 Aylık & 32 & 2012 Nisan & 2017 Aralık & 69 & $-118,31$ \\
\hline \multirow{3}{*}{$\underset{1}{\mathbb{2}}$} & İspir & Aylik & 126 & 2013 Mart & 2014 Mart & 13 & $-29,29 *$ \\
\hline & Sarıkamış & 3 Aylık & 66 & 2013 Temmuz & 2016 Nisan & 34 & $-59,60$ \\
\hline & Sarıkamış & 12 Aylık & 33 & 2012 Nisan & 2017 Aralık & 69 & $-143,57 *$ \\
\hline$\sqrt{v}$ & Sarıkamış & 12 Aylık & 26 & 2012 Nisan & 2017 Aralık & 69 & $-137,64$ \\
\hline
\end{tabular}

Not: * işareti en büyük değeri göstermektedir. 
Aylık, 3 aylık ve 12 aylık meteorolojik kuraklık indeksleri gidişler analizi sonuçları karşılaştırıldığında, maksimum kuraklıkların görüldüğü yıllar neredeyse aynı olduğu saptanmıştır (Tablo 5). Ayrıca kuraklıkların zamansal ve mekânsal dağılımının belirlenmesi için en şiddetli kuraklıkların görüldüğü 2014 yılı Şubat ayı seçilmiștir.

Tablo 5: Fırat Havzası'nda şiddetli kuraklıkların en çok görüldüğü yıllar

\begin{tabular}{cccccc}
\hline $\begin{array}{c}\text { Zaman } \\
\text { periyodu }\end{array}$ & SYİ & \multicolumn{2}{c}{ Maksimum kuraklıkların en yoğun görüldüğü yillar } \\
\hline Aylık & $1989,2013-2014$ & 1989 & 1989 & $1988,1989,2012-2014$ & KKİ \\
3 Aylık & $2011-2016$ & $2013-2014$ & $2012-2014$ & $1989,2012-2017$ & - \\
12 Aylık & $2012-2017$ & $2012-2015$ & $2012-2015$ & $2012-2017$ & $2012-2017$ \\
\hline
\end{tabular}

Boustani ve Ulke (2020) çalışmalarında, 7 farklı meteorolojik kuraklık indeksi ile Yeşilırmak havzası için aylık 1, 3, 6, 12, 24, 36 ve 48 zaman ölçeğindeki yağış zaman serileri kullanılarak kuraklık durumu incelenmiştir. Çalışmanın sonucunda 1974, 2001 ve 2014 yıllarında en şiddetli kuraklıklar tespit edilmiştir. Yapılan çalışma, büyük ölçüde mevcut çalışmamızı desteklemektedir. Ancak çalışma alanında genellikle 1974 ve 2001 yıllarında hafif kuraklık, 2014 yılında ise şiddetli kuraklıklar tespit edilmiştir.

SAİ analizleri sonucunda aylık maksimum hidrolojik kuraklıklar en çok 1971 - 1974, 1989 -1990 ve 1999 - 2002 yılları arasında meydana gelirken 3 aylık maksimum kuraklıklar ise en çok 2007, 2008 ve 1999 - 2002 yılları arasında görülmektedir. Ayrıca 12 aylık maksimum kuraklıklar en çok 1970 - 1976 ve 1999 - 2004 yılları arasında görülmektedir. SAİ analizleri sonucunda en şiddetli kuraklıkların görüldüğü yıllar arasında kuraklık sayısı ve şiddet değerlerine göre karşılaştırma yapılarak kuraklık haritaları için kritik zaman periyotları seçilmiştir. Bu nedenle hidrolojik kuraklıkların zamansal ve mekânsal dağılımının belirlenmesi için 2001 yılı Eylül, Ekim, Kasım ve Aralık ayları seçilmiştir.

Yıldız (2019) çalışmasında 1, 3, 6 ve 12 aylık Akım Kuraklık İndeksi (AKİ) değerleri hesaplanarak Fırat havzasında hidrolojik kuraklık analizi yapılııştır. Çalışmanın sonucunda havza bazında kuraklık oranlarının fazla olduğu yıllar 1973, 1989, 2001 ve 2008 yılları olarak tespit edilmiștir. Yapılan çalıșma hidrolojik kuraklıkların görüldüğü yıllar açısından neredeyse aynıdır. Farklı kuraklık yıllarının görülmesinde ise kullanılan kuraklık indeksleri ve istasyonların farklılığından kaynaklandığı düşünülmektedir.

\subsection{Meteorolojik Kuraklık Risk Haritaları}

Bu kısımda, her bir kuraklık indeksi ile belirlenen kuraklık şiddetlerine göre kuraklık sınıflarının havza üzerindeki zamansal ve mekânsal dağılımları Kriging, RTF ve TMAE yöntemleri ile belirlenmiş ve kuraklık risk haritaları oluşturulmuştur. 1 ve 3 aylık indeksler meteorolojik kuraklığı gösterirken, 12 aylık indeksler meteorolojik ve hidrolojik kuraklık durumunu hakkında bilgi vermektedir.

Ülkemizde kıyı bölgelerinde denizlerin etkisiyle daha ılıman iklim özellikleri görülürken Kuzey Anadolu Dağları ve Toros Dağları deniz etkilerinin iç kesimlere girmesini engel olmaktadır. Bu yüzden iç kesimlerde yer alan Fırat Havzası'nda düşük yağışlar nedeniyle şiddetli kuraklıklar görülmektedir. Bu çalışmada, en şiddetli kuraklıkların yaşandığı yıllardan biri olan 2014 yılı Şubat ayına ait 5 farklık kuraklık indeksinin kuraklık risk haritaları Şekil 4,5 ve 6'da gösterilmiştir. 

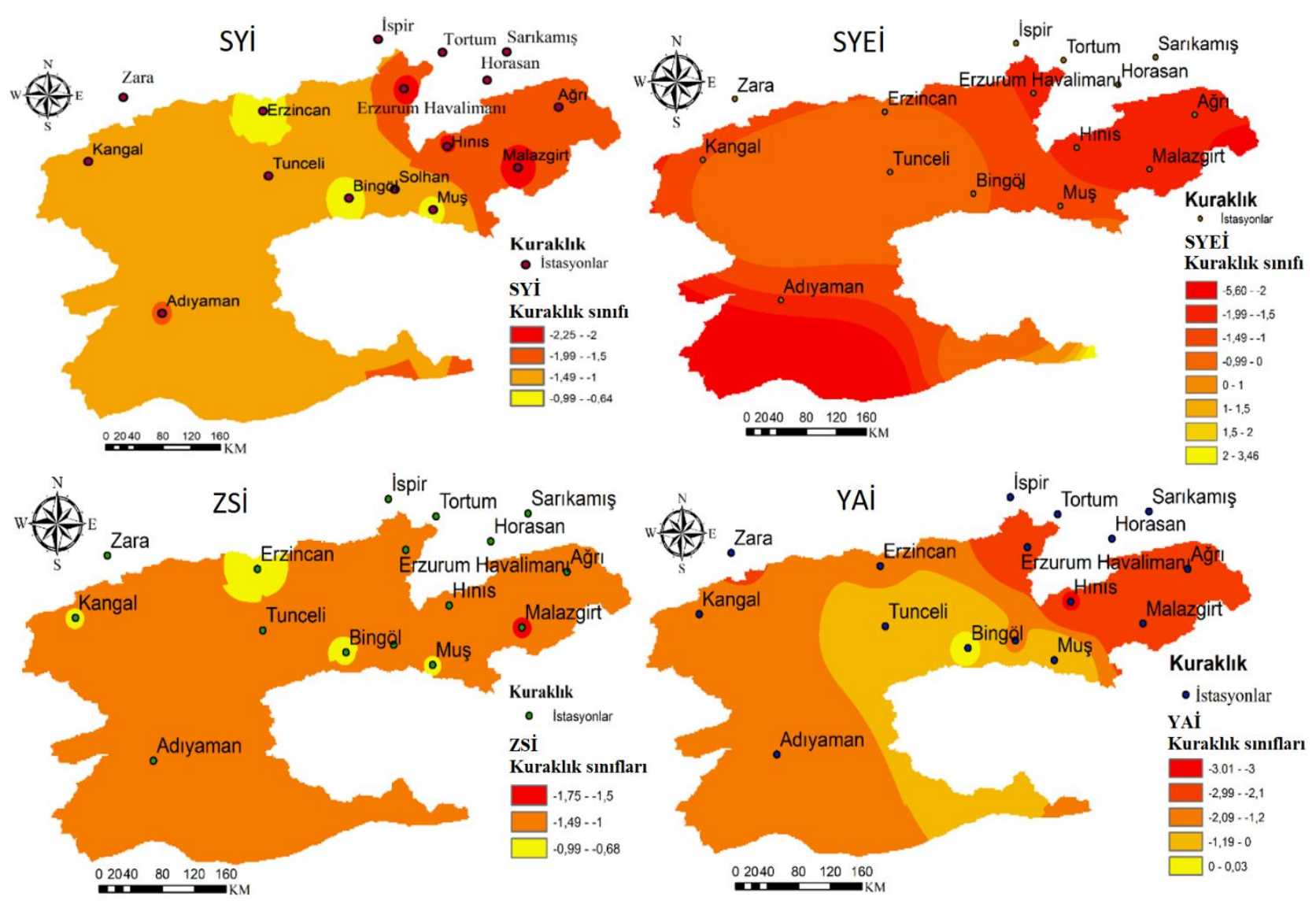

Şekil 4: 2014 yılı Şubat ayına ait aylık meteorolojik kuraklık risk haritaları

Şekil 4’te 2014 yılı Şubat ayına ait aylık SYİ, ZSİ ve YAİ değerlerinin determinisitk enterplasyon metotları (TMAE ve RTF) ile üretilen meteorolojik kuraklık haritaları incelendiğinde, kuraklık sınıflarının dağılımı açısından oldukça benzer haritalar elde edildiği görülmektedir. Bu indekslere göre havzanın büyük kısmında orta düzey kuraklıkların hâkim olduğu görülmüştür. SYEİ değerlerinin Kriging metodu ile elde edilen kuraklık haritasında ise havzanın genelinde şiddetli ve olağanüstü kuraklıkların hâkim olduğu görülmektedir. Bu durum, kuraklıkların mekânsal değişiminin incelenmesinde seçilen enterpolasyon metodu ve kuraklık indeksine göre büyük farklılık gösterdiği sonucuna varılmıştır. SYEİ hesabında diğer indekslerden farklı olarak PET değerlerinin de kullanılması önemli etkenlerden biridir.

Şekil 5'te 2014 yılı Şubat ayına ait 3 aylık SYEİ, ZSİ ve YAİ değerlerinin meteorolojik kuraklık haritaları incelendiğinde, havzanın büyük kısmında şiddetli ve olağanüstü kuraklıkların hâkim olduğu görülmektedir. SYİ değerlerinin kuraklık haritasına göre ise havzasın genelinde orta düzey kuraklıklar hâkimdir. Bu sonuçlar doğrultusunda, kuraklıkların mekânsal değişiminin incelenmesinde kuraklık indeksine göre farklı durumlar meydana gelebileceği tespit edilmiştir. Ayrıca SYEİ, PET değerlerini hesaba kattığı için değişen iklim koşullarını da içinde barındırdığından diğer meteorolojik kuraklık indekslerine göre olağanüstü kuraklıkların yayılımı haritada daha fazla yer kaplamıştır. 


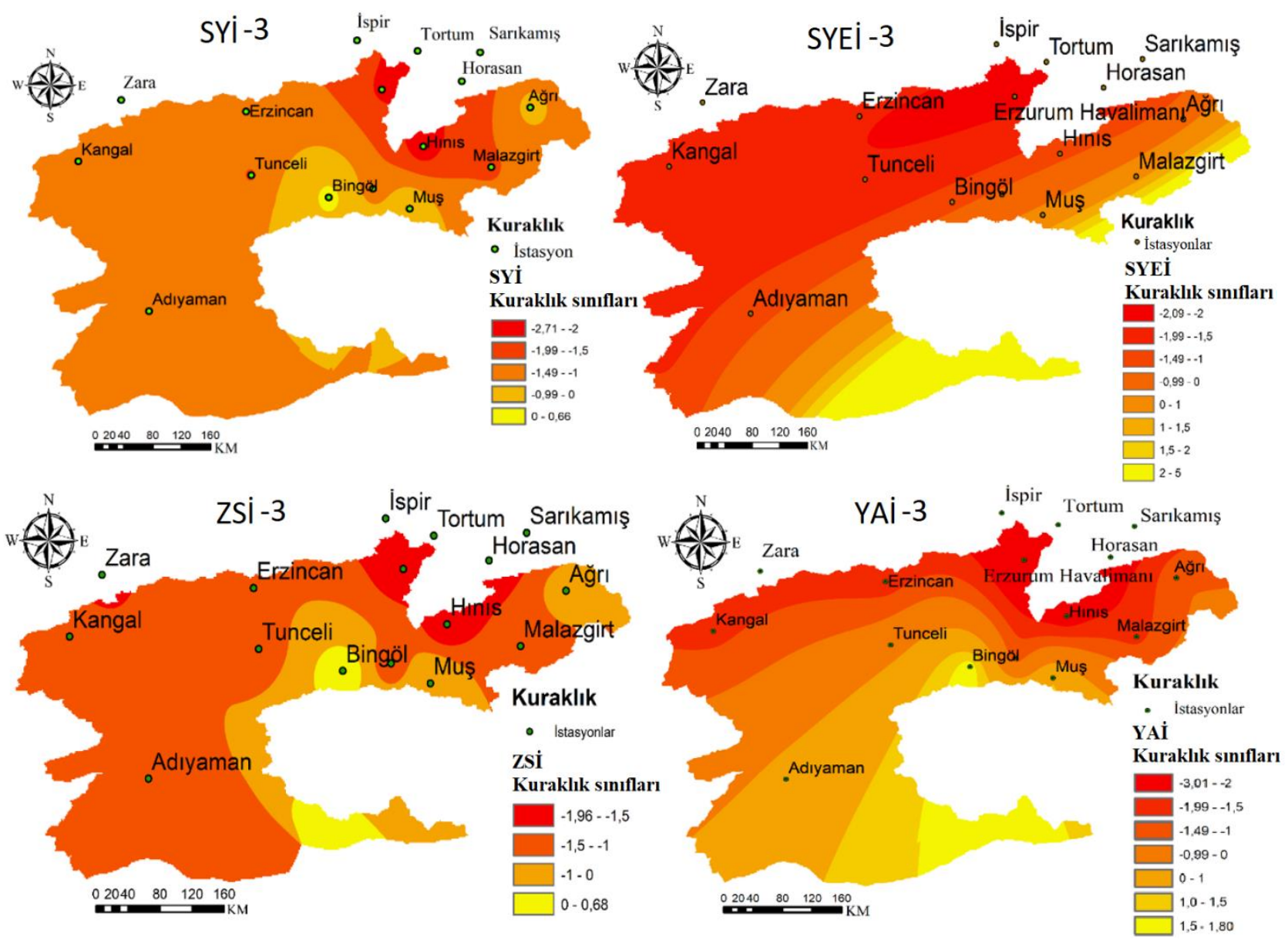

Şekil 5: 2014 yılı Şubat ayına ait 3 aylık meteorolojik kuraklık risk haritaları

Şekil 6'da 2014 yılı Şubat ayına ait 12 aylık SYİ, SYEİ, ZSİ ve KKİ değerlerinin kriging ile elde edilen hidrolojik kuraklık haritaları incelendiğinde havzanın kuzey ve güney kesimlerinde şiddetli ve olağanüstü kuraklıklar, orta kesimlerinde ise orta düzey ve hafif kuraklıkların öne çıktı̆̆ı görülmektedir. TMAE yöntemi ile elde edilen YAİ kuraklık haritalarında ise diğer indekslerden farklı olarak kuzey kesimlerde şiddetli ve orta düzey kuraklıklar görülürken güney kesimlerinde orta düzey kuraklıkların hâkim olduğu görülmektedir. Bu durum kuraklık haritalarının elde edilmesinde kullanılan enterpolasyon metodu, indeks tipi ve kesim seviyelerine göre farklı sonuçlar elde edilebileceğini göstermektedir. Ayrıca KKİ, PET değerlerini hesaba kattığı için diğer meteorolojik kuraklık indekslerine göre olağanüstü kuraklıkların yayılımı haritada daha fazla yer kaplamıştır. 


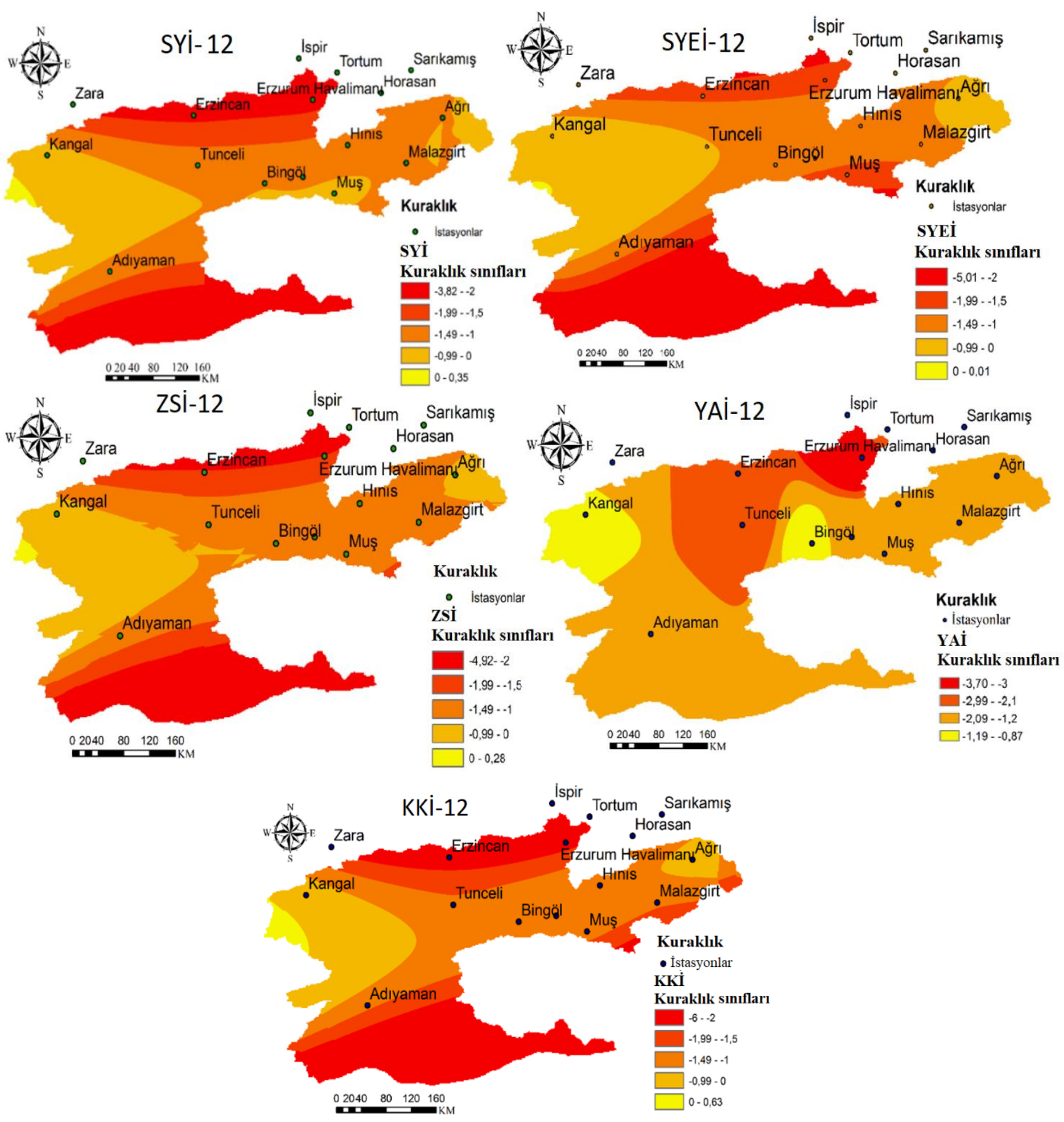

Şekil 6: 2014 yılı Şubat ayına ait 12 aylık KKI değerlerinin Kriging ile oluşturulan hidrolojik kuraklık risk haritası

Tablo 6'da çapraz geçerlilik testleri sonucunda, elde edilen HKOK değerleri gösterilmiştir. Bu değerler karşılaştırıldığında en küçük HKOK değerlerinin en iyi tahmin modelini göstermektedir. Bu kritere göre Kriging metodunun meteorolojik kuraklık tahminde, TMA ve RTF metotlarından daha etkinli olduğunu tespit edilmiştir. Ayrıca Tablo 7'de en uygun enterpolasyon yöntemlerinin sayısı ve yüzdesi sunulmuştur. 
Tablo 6: 2014 yılı şubat ayı meteorolojik kuraklıkların tahmininde kullanılan yöntemlere ait HKOK değerleri

\begin{tabular}{|c|c|c|c|}
\hline İndeks & Kriging & TMAE & RTF \\
\hline SYİ-1 & 0,50 & 0,49 & $\mathbf{0 , 4 8}$ \\
\hline SYEİ-1 & $\mathbf{0 , 6 1}$ & 0,64 & 0,62 \\
\hline ZSİ-1 & 0,67 & $\mathbf{0 , 3 5}$ & 0,48 \\
\hline YAİ-1 & 0,94 & $\mathbf{0 , 7 2}$ & 0,76 \\
\hline SYİ-3 & 1,72 & 0,87 & $\mathbf{0 , 8 6}$ \\
\hline SYEİ-3 & $\mathbf{1 , 0 1}$ & 1,05 & 1,02 \\
\hline ZSİ-3 & 0,85 & $\mathbf{0 , 7 4}$ & 0,79 \\
\hline YAİ-3 & 1,20 & 1,26 & $\mathbf{1 , 1 4}$ \\
\hline SYİ-12 & $\mathbf{0 , 5 1}$ & 0,73 & 0,65 \\
\hline SYĖं-12 & $\mathbf{0 , 8 5}$ & 0,88 & 1,10 \\
\hline ZSİ-12 & $\mathbf{0 , 6 8}$ & 0,73 & 0,71 \\
\hline YAİ-12 & 0,75 & $\mathbf{0 , 5 8}$ & 0,61 \\
\hline KKİ-12 & $\mathbf{0 , 8 1}$ & 1,01 & 1,15 \\
\hline
\end{tabular}

Tablo 7: 2014 yılı şubat ayına en iyi uyan enterpolasyon yöntemlerinin sayısı ve yüzdesi

\begin{tabular}{|c|c|c|c|c|}
\hline Enterpolasyon yöntemi & Aylık & 3 Aylık & 12 Aylık & Toplam \\
\hline Kriging & 1 & 1 & 4 & $6(\% 46,15)$ \\
\hline TMAE & 2 & 1 & 1 & $4(\% 30,77)$ \\
\hline RTF & 1 & 2 & - & $3(\% 23,07)$ \\
\hline
\end{tabular}

Mevcut araştırmalar, jeoistatistik enterpolasyon yöntemlerinin seyrek dağılmış istasyonlarda ve yüksekliğin kısa mesafede büyük farklılıklar gösterdiği bölgelerde yani dağlık bölgelerde yağış ani değişim göstermesinden dolayı deterministik enterpolasyon yöntemlerinden daha iyi performans gösterdiğini tespit etmişstir (Dirks vd. 1998; Goovaerts 2000; Kuzucu 2016). Yani jeoistatistik bir metot olan Kriging yöntemi, deterministik TMAE ve RTF metotlarından daha iyi sonuç vermektedir. Bu çalışmada kullanılan istasyonların yoğun ve homojen bir dağılıma sahip olmaması ve havzanın kuzey kesiminin dağlı olması nedeniyle kriging yönteminin daha tutarlı tahmin sonuçları göstermesi mevcut çalışmayı destekler nitelikte olmaktadır. Havzanın yukarı Fırat bölümünün dağlık olması yağış ve sıcaklıklarda mesafeye bağlı ani değişimlerin meydana gelmesine ve dolayısıyla kuraklık indekslerinin mekânsal değișiminin büyük olmasına neden olmaktadır. Bu mekânsal değişimin modellenmesi ise jeoistatistiksel Kriging metodu ile etkili bir biçimde yapılabildiği görülmektedir.

Subedi vd. 2019 çalışmalarında, SYEI değerlerini kullanarak ABD Doğu Teksas'ta kuraklık dağılım haritası oluşturmak için farklı mekansal enterpolasyon tekniklerini analiz etmişlerdir. Çalışmanın sonucunda deterministik [TMAE ve spline] ve Jeoistatistiksel [sıradan kriging (SK) ve küresel kriging (KS)] enterpolasyon teknikleri, değerlendirme için aday yöntemler olarak kullanılmıştır. Sonuçlar, KG'nin nispeten daha kuru koşullarda iyi performans gösterme eğiliminde olduğunu, IDW'nin ise karışık sonuçlar gösterdiğini ve hem kuru hem de 1slak koşullarda iyi performans gösterdiğini göstermektedir. Genel olarak, en küçük hata HKOK değerlerini veren KG ve TMAE yöntemlerinin meteorolojik kuraklık haritalanmasında iyi performans sergilediği tespit edilmiştir. Yapılan çalışmamız ifade edilen çalışmaya ile karşılaştırıldığında çalışma alanlarının topografik yapısı, istayonların sayısı ve dağılımı nedeniyle farklık göstermektedir.

\subsection{Hidrolojik Kuraklık Risk Haritaları}

Bu kısımda, SAİ ile belirlenen hidrolojik kuraklık sınıflarının havza üzerindeki zamansal ve mekânsal dağılımları Kriging, TMAE ve RTF yöntemleri ile belirlenmiş ve kuraklık risk haritaları oluşturulmuştur. Daha önce yapılan gidişler analizi sonucunda en şiddetli hidrolojik kurak 2001 yılında görüldüğü için bu yıl kuraklık enterpolasyon haritalarının çizilmesinde referans olarak alınmıştır.

Şekil 7-9'da 2001 yılında havzada en şiddetli hidrolojik kuraklıkların görüldüğü Eylül, Ekim, Kasım ve Aralık aylarına ait kuraklık şiddetleri enterpolasyon haritaları örnek olarak gösterilmiştir. Hidrolojik kuraklık haritalarında havza genelinde olağanüstü, şiddetli ve orta düzey kuraklıkların hâkim olduğu görülmektedir.

Şekil 7'de verilen aylık SAİ değerlerinin mekânsal kuraklık değişim haritalarında, eylül ayında hafif, ekim ve kasım ayında şiddetli, aralık aylarında ise havzanın kuzeyinde hafif kuraklıkların havzada hâkim olduğu görülmektedir. Fırat havzası karma rejimli bir yapıya sahip olduğu için akım miktarı yağış, kar erimesi, yeraltı suyu ve bitki örtüsüne bağlı olarak değişmektedir. Çalışma havzasında akımların yaklaşık \%70’i kar erimesine bağlı olması ve erimenin ilkbaharda etkili ancak sonbaharda etkisiz olması eylül, ekim, kasım ve aralık aylarında şiddetli kuraklıkların geniş yer kaplamasına neden olmuştur. 


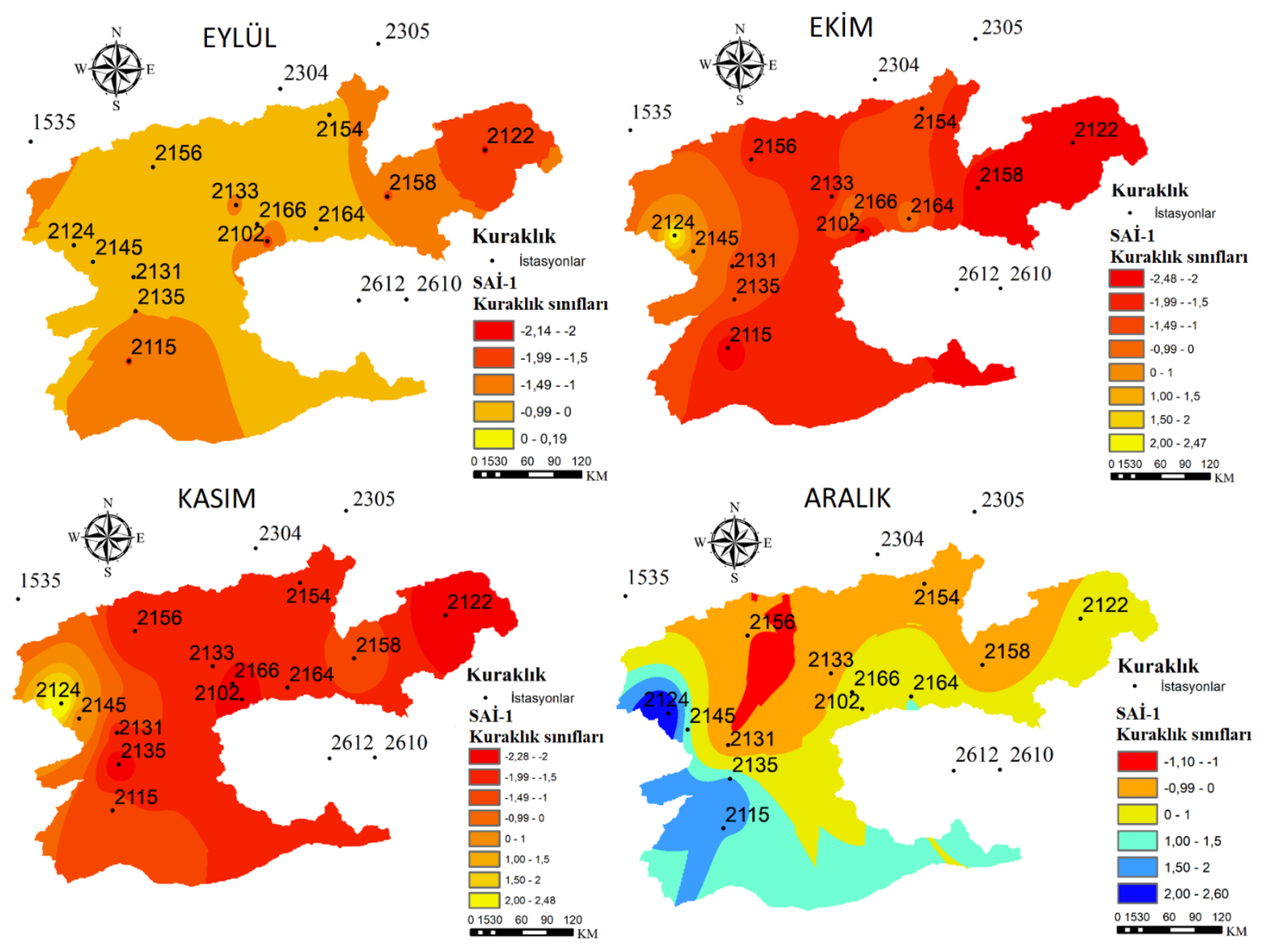

Şekil 7: 2001 yılı aylık SAl değerlerinin hidrolojik kuraklık risk haritaları

Şekil 8'de verilen 3 aylık SAİ değerlerinin mekânsal kuraklık değişim haritalarında, eylül ayında hafif, ekim ayında orta düzey, kasım ayında olağanüstü, aralık aylarında ise şiddetli kuraklıkların havzada hâkim olduğu görülmektedir. Şekil 9'da verilen 12 aylık SAİ değerlerinin mekânsal kuraklık değişim haritalarında, eylül, ekim ve kasım ayında olağanüstü ve şiddetli, aralık aylarında ise orta düzey kuraklıkların havzada hâkim olduğu görülmektedir. Ayrıca 12 aylık meteorolojik indeks haritaları ile hidrolojik indeks haritaları ile büyük benzerlik sergilediği tespit edilmiştir. 


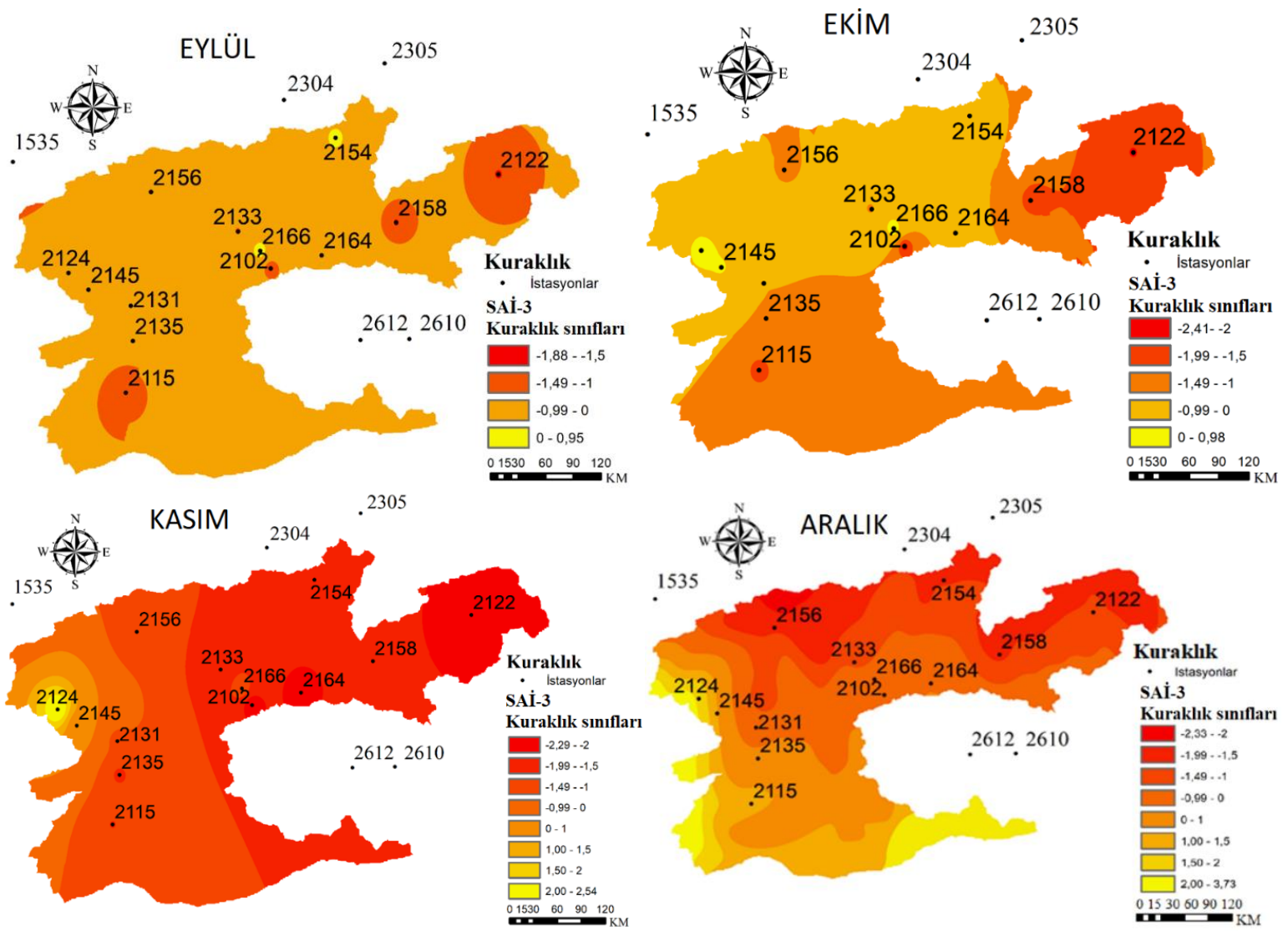

Şekil 8: 2001 yılı 3 aylık SAi değerlerinin hidrolojik kuraklık risk haritaları
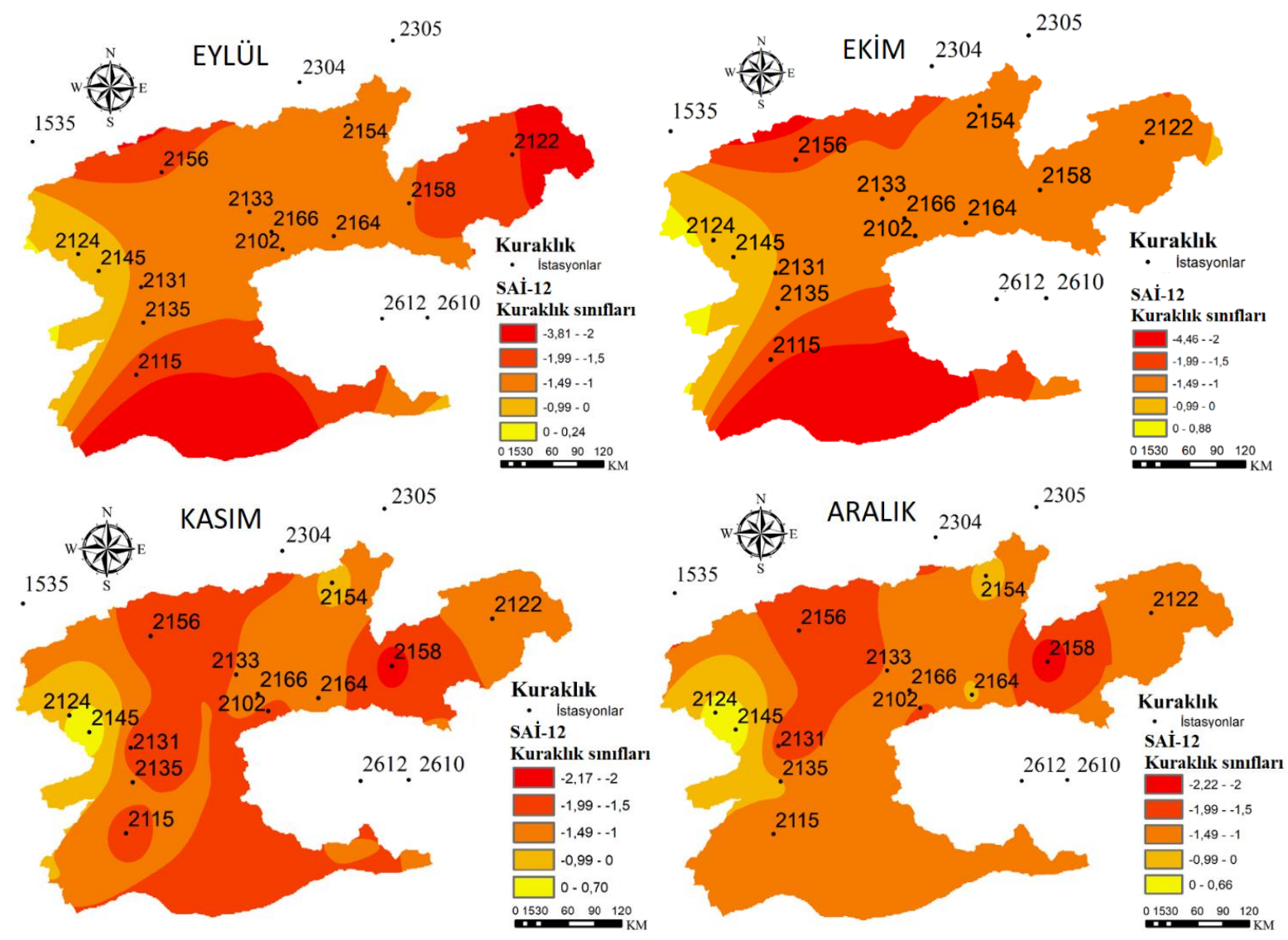

Şekil 9: 2001 yılı 12 aylık SAl değerlerinin hidrolojik kuraklık risk haritaları 
Tablo 8 ve Tablo 9'da Kriging, TMAE ve RTF yöntemlerine ait elde edilen HKOK değerleri incelendiğinde, hidrolojik kuraklık haritalarının üretilmesinde RTF metodunun, TMAE ve Kriging yöntemine göre oldukça üstün olduğu tespit edilmiştir. Bu durum akım gözlem istasyonlarının oldukça homojen bir dağılım sergilemesi ve meteoroloji istasyonlara göre sayısının bir miktar fazla olması ile açıklanabilmektedir.

Tablo 8: 2001 yılı hidrolojik kuraklıkların tahmininde kullanılan yöntemlere ait HKOK değerleri

\begin{tabular}{|c|c|c|c|}
\hline & Kriging & TMAE & RTF \\
\hline Eylül-SAİ-1 & 1,26 & 0,99 & $\mathbf{0 , 9 5}$ \\
\hline Ekim-SAİ-1 & 1,27 & 1,21 & $\mathbf{1 , 2 0}$ \\
\hline Kasım-SAİ-1 & 1,01 & $\mathbf{0 , 8 0}$ & 1,53 \\
\hline Aralık-SAİ-1 & 1,03 & 1,10 & $\mathbf{1 , 0 0}$ \\
\hline Eylül-SAİ-3 & 1,12 & $\mathbf{1 , 0 6}$ & 1,08 \\
\hline Ekim-SAİ-3 & 1,25 & 1,19 & $\mathbf{1 , 1 8}$ \\
\hline Kasım-SAİ-3 & 1,45 & $\mathbf{0 , 8 4}$ & 1,19 \\
\hline Aralı-SAİ-3 & $\mathbf{1 , 6 7}$ & 1,68 & 1,90 \\
\hline Eylül-SAİ-12 & $\mathbf{0 , 8 2}$ & 0,83 & 1,20 \\
\hline Ekim-SAİ-12 & $\mathbf{0 , 7 1}$ & 0,86 & 0,90 \\
\hline Kasım-SAİ-12 & 0,76 & 0,77 & $\mathbf{0 , 7 3}$ \\
\hline Aralık-SAİ-12 & 0,78 & 0,84 & $\mathbf{0 , 6 5}$ \\
\hline
\end{tabular}

Not: Kalın karakterler en uygun modeli göstermektedir.

Tablo 9: 2001 yılı hidrolojik kuraklıkların enterpolasyonunda kullanılan yöntemlerin sayısı ve yüzdesi

\begin{tabular}{|c|c|c|c|c|}
\hline Enterpolasyon yöntemi & Aylık & 3 Aylık & 12 Aylık & Toplam \\
\hline Kriging & - & 1 & 2 & $3(\% 25)$ \\
\hline TMAE & 1 & 2 & - & $3(\% 25)$ \\
\hline RTF & 3 & 1 & 2 & $\mathbf{6}(\% 50)$ \\
\hline
\end{tabular}

Not: Kalın karakterler en uygun modeli göstermektedir.

\section{Sonuç ve Öneriler}

Bu çalışma iklim değişikliği nedeniyle kuraklık açısından riskli ve sınırları aşan sular kapsamında jeopolitik öneme sahip olan Fırat Havzası'ndaki meteorolojik ve hidrolojik kuraklıkların analizi için yapılmıştır. Çalışma kapsamında 1966-2017 yılları arasını kapsayan 16 adet meteoroloji gözlem istasyonu ve 1970-2009 yılları arasını kapsayan 18 adet akım gözlem istasyonu kullanılmıştır. Havza düzeyinde çeşitli meteorolojik ve hidrolojik kuraklık indeksleri aracılığıyla kuraklık şiddetlerinin zamansal ve mekânsal değişimi belirlenmiş ve havzadaki kuraklık açısından riskli bölgeler tespit edilerek aşağıdaki sonuçlar elde edilmiştir.

Fırat havzasındaki kuraklık karakteristikleri incelendiğinde en şiddetli ve en uzun süreli meteorolojik kuraklıklar genellikle 2012 ile 2017 ve hidrolojik kuraklıklar 1999 ile 2004 yılları arasında olduğu tespit edilmiştir. Uzun süreli ve şiddetli kuraklıkların havzada hâkim olması gelecekte görülmesi muhtemel kuraklıklara karşı önlemeler alınarak risk yönetimi çalışmaları ile kuraklık etkisinin azaltılması gerekmektedir.

Meteorolojik ve hidrolojik kuraklıkların tahmini için Kriging, RTF ve TMA yöntemleri karşılaştırılmıştır. Karşılaştırma işlemi çapraz geçerlilik testi sonucu elde edilen HKOK değerlerine göre yapılmıştır. Havzada meteoroloji istasyonları homojen bir şekilde dağılmadığı için meteorolojik kuraklıkların tahmininde, jeoistatistik bir metot olan Kriging metodu, TMA ve RTF gibi deterministik enterpolasyon metotlarından daha iyi performans sergilemiştir. Akım gözlem istasyonları ise oldukça homojen bir dağılım sergilemesi ve nispeten sayısının fazla olması nedeniyle deterministik enterpolasyon yöntemi olan RTF ile daha etkili tahminler yapılmıştır.

Kuraklıkların mekânsal değişiminin incelenmesinde seçilen enterpolasyon metodu ve kuraklık indeksine göre kuraklık sınıfının dağılımında büyük farklılıklar tespit edilmiştir. Ayrıca KKİ ve SYEİ, PET değerlerini hesaba kattığı için değişen iklim koşullarını da içinde barındırdığından genellikle diğer meteorolojik kuraklık indekslerine göre olağanüstü kuraklıkların yayılımı haritada daha fazla yer kaplamaktadır.

Kuraklık haritaları ile riskli bölgeler tespit edilmiş ve bu bölgelerde önlemlerin alınarak tekrarlanması muhtemel kuraklıkların etkisinin azaltılması gerektiği vurgulanmıştır. Aylık ve 3 aylık zaman periyodunda özellikle havzanın kuzey kesimlerinde bulunan Erzincan, Erzurum, Hınıs, Ağrı, Malazgirt meteoroloji istasyonlarda 2014 yılı Şubat ayında şiddetli ve olağanüstü kuraklıklar nedeniyle risk altında olduğu tespit edilmiştir. 12 aylık zaman periyodunda ise özellikle havzanın en kuzey ve en güneyindeki Erzincan, Erzurum, Tunceli, Adıyaman istasyonunda şiddetli ve olağanüstü kuraklıklar nedeniyle risk altında olduğu tespit edilmiştir. 
Hidrolojik kuraklık açısından aylık zaman periyodunda 2001 yılı Eylül ayında havzanın kuzeydoğusunda, Ekim ve Kasım aylarında havzanın tamamında şiddetli ve olağanüstü kuraklıkların hâkim olduğu görülmektedir. 3 aylık zaman periyodunda 2001 yılı Eylül ve Ekim aylarında havzanın kuzeydoğusunda, Kasım ayında havzanın tamamında ve Aralık ayında ise havzanın kuzey kesiminde şiddetli ve olağanüstü kuraklıkların hâkim olduğu görülmektedir. 12 aylık zaman periyodunda havzanın kuzey ve güney kesimlerinde, 2001 yılı Kasım ayında havzanın büyük kısmında, Aralık ayında ise havzanın kuzey kesimlerinde şiddetli ve olağanüstü kuraklıklar nedeniyle risk altında olduğu tespit edilmiştir.

Türkiye, Suriye ve Irak gibi Fırat Nehrinin geçtiği kıyıdaş Orta Doğu ülkelerinde kuraklık etkilerinin su kullanan tüm sektörleri (içme-kullanma, tarım, sanayi, ekosistem, su enerjisi, vb.) olumsuz etkileyeceği tespit edilmiştir. Bu etkiler sonucunda su paylaşımı nedeniyle jeopolitik gerginliğin artması beklenmektedir. Bu durumlara karşı hazırlıklı olunması, önlemlerin alınarak kuraklık etkilerin azaltılması ve su kaynaklarının etkili bir şekilde kullanılması gerektiği sonucuna varılmıştır.

\section{Teşekkür}

$\mathrm{Bu}$ çalışma kapsamında kullanılan aylık yağış ve sıcaklık verilerini temin eden Devlet Meteoroloji İşleri Genel Müdürlüğ̈’ne ve aylık akım verileri temin eden mülga Elektrik İşleri Etüt İdaresi Genel Müdürlüğü'ne teşekkür ederiz.

\section{Kaynaklar}

Afzali A., Keshtkar H., Pakzad S., Moazami N., Azizabadi Farahani E., Golpaygani A., Khosrojerdi E., Yousefi Z., TaghiNaghilou M., (2016), Spatio-temporal analysis of drought severity using drought indices and deterministic and geostatistical methods (Case Study: Zayandehroud River Basin), Desert, 21(2), 165-172.

Ali M.G., Younes K., Esmaeil A., Fatemeh T., (2011), Assessment of geostatistical methods for spatial analysis of SPI and EDI drought indices, World Applied Sciences Journal, 15(4), 474-482.

Amini M.A., Torkan G., Eslamian, S., Zareian, M.J., Adamowski, J.F., (2019), Analysis of deterministic and geostatistical interpolation techniques for mapping meteorological variables at large watershed scales, Acta Geophysica, 67(1), 191-203.

Anisfeld S.C., (2011), Water resources: Island Press, Washington, DC., USA, 321ss.

Aytemiz L., Kodaman T., (2006), Sınır aşan sular kullanımı ve Türkiye-Suriye ilişkileri, Tmmob Su Politikaları Kongresi, $527-537$.

Bajjali W., (2017), ArcGIS for environmental and water issues, Springer International Publishing, 353ss.

Boustani A., Ulke A., (2020), Investigation of Meteorological Drought Indices for Environmental Assessment of Yesilirmak Region, Journal of Environmental Treatment Techniques, 8(1), 374-381.

Buttafuoco G., Caloiero T., Coscarelli R., (2015), Analyses of drought events in Calabria (Southern Italy) using standardized precipitation index, Water Resources Management, 29(2), 557-573.

Chenoweth M.E., Sarra S.A., (2009), A numerical study of generalized multiquadric radial basis function interpolation, SIAM Undergraduate Research Online, 2(2), 58-70.

Dirks K.N., Hay J.E., Stow C.D., Harris D., (1998), High-resolution studies of rainfall on Norfolk Island: Part II: Interpolation of rainfall data, Journal of Hydrology, 208(3-4), 187-193.

Goovaerts P., (2000), Geostatistical approaches for incorporating elevation into the spatial interpolation of rainfall, Journal of hydrology, 228(1-2), 113-129.

Gümüș V., (2017), Akim kuraklık indeksi ile Asi havzasının hidrolojik kuraklık analizi, Gazi Üniversitesi Fen Bilimleri Dergisi Part C: Tasarım ve Teknoloji, 5(1), 65-73.

Gümüș V., Yıldız M.S., Șimșek O., (2018), Hidrolojik Kuraklık Değerlendirmesi: Murat Nehri-Palu Örneği, Harran Üniversitesi Mühendislik Dergisi, 3(3), 297-301.

IPCC, (2007), Climate Change 2007 - Impacts, Adaptation and Vulnerability, Intergovernmental Panel on Climate Change fourth assessment report on scientific aspects of climate change for researchers, students, and policymarkers, Cambridge University Press, New York, NY, USA, 987ss.

Isaaks E., Srivastava R., (1989), An introduction to applied geostatistics, Oxford University Press, ss.561.

Johnston K., Ver Hoef J.M., Krivoruchko K., Lucas N., (2001), Using ArcGIS geostatistical analyst (Vol. 380), ESRI Redlands.

Karabulut M. (2020), Standart yă̆ış indeksi kullanılarak Sivas il'inde kuraklık analizi, Uluslararası Sosyal Araştırmalar Dergisi, 13(71), 2017-230.

Katipoğlu O.M., Acar R., Şengül S., (2020), Comparison of meteorological indices for drought monitoring and evaluating: A case study from Euphrates basin, Turkey, Journal of Water and Climate Change, 11(S1), 29-43.

Katipoğlu, O.M., Acar, R., Şenocak, S., (2021), Spatio-temporal analysis of meteorological and hydrological droughts in the Euphrates Basin, Turkey. Water Supply, 21(4), 1657-1673.

Kuzucu A., (2016), Seyhan Havzası'nda Kuraklı̆̆ın Zamansal ve Alansal Değişiminin İncelenmesi, Yüksek Lisans Tezi, Dokuz Eylül Üniversitesi, İzmir.

Li X., Sha J., Wang Z. L. (2019), Comparison of drought indices in the analysis of spatial and temporal changes of climatic drought events in a basin, Environmental Science and Pollution Research, 26(11), 10695-10707.

Lilly J.O., (2016), A GIS Approach to Modeling Groundwater Levels in the Mississippi River Valley Alluvial Aquifer, Msc thesis. University of Arkansas, Arkansas.

Mahajan D.R., Dodamani, B.M., (2016), Spatial and temporal drought analysis in the Krishna river basin of Maharashtra, India, Cogent Engineering, 3(1), 1185926

Manikandan M., Tamilmani D., (2015), Spatial and Temporal Variation of Meteorological Drought in the Parambikulam-Aliyar Basin, Tamil Nadu, Journal of The Institution of Engineers (India): Series A, 96(3), 177-184. 
McKee T.B., Doesken N.J., Kleist J., (1993), The relationship of drought frequency and duration to time scales, Paper presented at the Proceedings of the 8th Conference on Applied Climatology, 17-22 January, Anaheim, California.

Mishra S.S., Nagarajan R., (2011), Spatio-temporal drought assessment in Tel river basin using Standardized Precipitation Index (SPI) and GIS, Geomatics, Natural Hazards and Risk, 2(1), 79-93.

Morid S., Smakhtin V., Moghaddasi M. (2006), Comparison of seven meteorological indices for drought monitoring in Iran. International Journal of Climatology: A Journal of the Royal Meteorological Society, 26(7), 971-985.

Nasrollahi M., Khosravi H., Moghaddamnia A., Malekian A., Shahid S., (2018), Assessment of drought risk index using drought hazard and vulnerability indices, Arabian Journal of Geosciences, 11(20), 606, doi: 10.1007/s12517-018-3971-y.

Özcan M., (2020), Dicle Havzasının zamansal ve mekânsal kuraklık analizi, Yüksek Lisans Tezi, Harran Üniversitesi Fen Bilimleri Enstitüsü, Şanlıurfa.

Rahman M.R., Lateh H., (2016), Meteorological drought in Bangladesh: assessing, analysing and hazard mapping using SPI, GIS and monthly rainfall data, Environmental Earth Sciences, 75(12), 1026, doi: 10.1007/s12665-016-5829-5.

Shukla S., Wood A.W., (2008), Use of a standardized runoff index for characterizing hydrologic drought, Geophysical research letters, 35(2), doi: 10.1029/2007GL032487.

Subedi M.R., Xi W., Edgar C.B., Rideout-Hanzak S., Hedquist, B.C., (2019), Assessment of geostatistical methods for spatiotemporal analysis of drought patterns in East Texas, USA. Spatial Information Research, 27(1), 11-21.

Tsakiris G., Vangelis H.J.E.W., (2005), Establishing a drought index incorporating evapotranspiration. European water, 9(10), 3-11.

URL-1 (2020). Geostatical analyst- Evaluating interpolation results- Performing cross-validation and validation. ArcGIS Desktop extensions. https://desktop.arcgis.com/en/arcmap/latest/extensions/geostatistical-analyst/performing-cross-validation-andvalidation.htm, [Erişim 3 Nisan 2021].

Van Rooy M.P., (1965). A rainfall anomaly index independent of time and space. Weather Bureau South Africa Journal, 14(6), $43-48$.

Vicente-Serrano S.M. Beguería S. López-Moreno J.I., (2010). A multiscalar drought index sensitive to global warming: the standardized precipitation evapotranspiration index. Journal of climate, 23(7), 1696-1718.

Wable P.S., Jha M.K., Shekhar A. (2019), Comparison of drought indices in a semi-arid river basin of India. Water resources management, 33(1), 75-102.

Wilhite D.A., (2005), Drought and water crises: science, technology, and management issues, CRC Press, 432ss.

Yıldırım A., (2006), Karakaya barajı ve doğal çevre etkileri, DÜ Ziya Gökalp Eğitim Fakültesi Dergisi, 6, 32-39.

Yıldız, M.S., (2019), Akım kuraklık indeksi yöntemi ile firat havzasinın hidrolojik kuraklık analizi/Hydrological drought analysis of euphrates basin with streamflow drought index method, Yüksek Lisans Tezi, Harran Üniversitesi Fen Bilimleri Enstitüsü, Şanliurfa.

Yuan S., Quiring S.M., Patil S., (2016), Spatial and temporal variations in the accuracy of meteorological drought indices, Cuadernos de Investigación Geográfica, 42(1), 167-183. 
EKLER

Ek-1: Çalışmada kullanılan yağı̧s istasyonlarına ait bazı istatistik bilgiler

\begin{tabular}{|c|c|c|c|c|c|c|c|c|c|c|c|c|c|}
\hline İstasyon & İstatist. & Ocak & Şubat & Mart & Nisan & Mayıs & Haziran & Temmuz & Ağustos & Eylül & Ekim & Kasım & Aralık \\
\hline \multirow{3}{*}{ 妾 } & Max & 367,1 & 233,0 & 348,5 & 223,9 & 146,8 & 51,1 & 10,5 & 16,9 & 44,7 & 162,8 & 232,8 & 331,6 \\
\hline & Min & 7,0 & 1,0 & 4,9 & 3,9 & 1,8 & 0,0 & 0,0 & 0,0 & 0,0 & 1,0 & 0,0 & 0,3 \\
\hline & Ort. & 136,7 & 98,0 & 89,6 & 66,8 & 39,9 & 8,1 & 1,8 & 1,5 & 6,4 & 46,3 & 76,8 & 131,3 \\
\hline \multirow{3}{*}{ 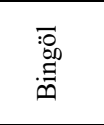 } & Max & 421,1 & 298,1 & 284,4 & 333,5 & 238,9 & 91,6 & 39,1 & 43,4 & 64,4 & 220,9 & 236,6 & 377,8 \\
\hline & Min & 1,3 & 25,6 & 36,1 & 12,8 & 9,1 & 0,0 & 0,0 & 0,0 & 0,0 & 4,4 & 0,6 & 3,4 \\
\hline & Ort. & 136,3 & 132,4 & 128,8 & 119,4 & 75,2 & 21,5 & 6,2 & 5,6 & 13,5 & 67,4 & 106,5 & 130,9 \\
\hline \multirow{3}{*}{$\stackrel{\text { L }}{\sum_{\Sigma}^{2}}$} & Max & 214,7 & 255,3 & 197,2 & 235,4 & 226,6 & 77,7 & 30,0 & 57,5 & 73,4 & 189,9 & 227,6 & 219,9 \\
\hline & Min & 1,1 & 18,9 & 17,3 & 21,6 & 2,9 & 0,0 & 0,0 & 0,0 & 0,0 & 1,1 & 0,4 & 2,5 \\
\hline & Ort. & 91,8 & 97,0 & 104,1 & 106,6 & 69,2 & 27,8 & 7,9 & 8,5 & 15,9 & 62,1 & 88,0 & 89,5 \\
\hline \multirow{3}{*}{$\frac{\dot{J}}{\frac{\pi}{\pi}}$} & Max & 82,6 & 93,2 & 109,2 & 165,8 & 175,1 & 76,2 & 39,5 & 25,8 & 75,9 & 129,3 & 126,3 & 118,1 \\
\hline & Min & 3,2 & 0,8 & 6,5 & 13,2 & 3,7 & 0,4 & 0,0 & 0,0 & 0,0 & 0,4 & 0,2 & 1,5 \\
\hline & Ort. & 33,9 & 36,8 & 50,4 & 73,2 & 70,8 & 29,7 & 11,2 & 5,2 & 15,2 & 47,9 & 44,4 & 38,3 \\
\hline \multirow{3}{*}{ 薜 } & Max & 149,6 & 254,5 & 96,9 & 141,4 & 151,6 & 143,7 & 76,3 & 55,6 & 72,6 & 160,7 & 126,5 & 110,6 \\
\hline & Min & 2,4 & 3,9 & 3,2 & 15,5 & 15,7 & 0,0 & 0,2 & 0,2 & 0,2 & 1,5 & 0,0 & 2,1 \\
\hline & Ort. & 40,7 & 46,8 & 49,3 & 71,8 & 73,8 & 42,7 & 20,1 & 13,3 & 19,8 & 55,9 & 46,7 & 44,0 \\
\hline \multirow{3}{*}{$\begin{array}{l}\overline{\bar{\Xi}} \\
\stackrel{\Xi}{\Xi} \\
\text { E }\end{array}$} & $\operatorname{Max}$ & 540,2 & 210,1 & 285,6 & 320,2 & 271,4 & 72,0 & 21,0 & 59,6 & 87,3 & 216,7 & 237,0 & 336,0 \\
\hline & Min & 1,1 & 2,6 & 19,2 & 14,9 & 4,7 & 0,2 & 0,0 & 0,0 & 0,0 & 0,9 & 0,2 & 5,0 \\
\hline & Ort. & 128,1 & 102,5 & 107,0 & 106,1 & 71,2 & 18,1 & 4,9 & 6,7 & 17,0 & 62,2 & 96,2 & 124,4 \\
\hline \multirow{3}{*}{ 員 } & Max & 159,1 & 171,6 & 163,0 & 177,3 & 191,0 & 96,4 & 49,4 & 44,0 & 60,0 & 184,3 & 127,1 & 155,1 \\
\hline & Min & 0,0 & 0,0 & 0,0 & 0,0 & 0,5 & 0,0 & 0,0 & 0,0 & 0,0 & 0,0 & 0,0 & 0,0 \\
\hline & Ort. & 49,7 & 58,1 & 71,7 & 81,5 & 68,4 & 30,4 & 13,6 & 10,7 & 16,7 & 52,4 & 55,0 & 54,4 \\
\hline \multirow{3}{*}{ 离 } & Max & 55,7 & 90,0 & 122,6 & 147,7 & 129,0 & 112,6 & 92,6 & 63,0 & 81,4 & 210,8 & 81,0 & 52,8 \\
\hline & Min & 1,7 & 1,2 & 1,2 & $\begin{array}{l}8,8 \\
\end{array}$ & 14,9 & 2,9 & 0,8 & 0,0 & 0,0 & 2,3 & 2,6 & 5,0 \\
\hline & Ort. & 19,7 & 22,5 & 32,0 & 53,6 & 69,6 & 44,6 & 24,9 & 17,5 & 22,4 & 49,3 & 31,1 & 21,1 \\
\hline \multirow{3}{*}{ 窇 } & Max & 74,9 & 62,7 & 100,4 & 95,9 & 138,2 & 64,1 & 81,0 & 26,2 & 46,4 & 130,9 & 124,3 & 89,8 \\
\hline & Min & 1,0 & 4,2 & 1,0 & 8,7 & 11,9 & 3,1 & 0,0 & 0,0 & 0,0 & 0,2 & 0,2 & 2,8 \\
\hline & Ort. & 27,6 & 29,1 & 41,7 & 53,6 & 55,0 & 29,2 & 12,0 & 7,1 & 15,1 & 44,0 & 37,1 & 28,0 \\
\hline \multirow{3}{*}{ 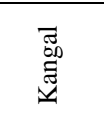 } & Max & 83,7 & 127,1 & 164,2 & 117,0 & 139,1 & 132,2 & 62,9 & 65,3 & 86,4 & 118,9 & 156,9 & 108,2 \\
\hline & Min & 3,9 & 1,4 & 2,3 & 10,1 & 12,7 & 0,3 & 0,0 & 0,0 & 0,2 & 2,2 & 0,7 & 2,8 \\
\hline & Ort. & 37,7 & 34,1 & 41,7 & 59,6 & 58,5 & 34,8 & 8,5 & 8,6 & 13,6 & 33,0 & 35,5 & 39,5 \\
\hline \multirow{3}{*}{ :0.00 } & Max & 96,2 & 117,8 & 110,2 & 139,6 & 128,4 & 84,0 & 58,1 & 53,8 & 72,6 & 126,5 & 142,7 & 129,9 \\
\hline & Min & 0,0 & 0,0 & 3,4 & 5,6 & 11,8 & 3,8 & 0,0 & 0,0 & 0,2 & 0,0 & 0,0 & 0,0 \\
\hline & Ort. & 31,6 & 34,2 & 40,6 & 57,6 & 60,8 & 41,9 & 24,1 & 16,5 & 22,5 & 42,3 & 43,0 & 39,7 \\
\hline \multirow{3}{*}{$\stackrel{\overrightarrow{0}}{\stackrel{0}{0}}$} & Max & 71,1 & 89,8 & 96,9 & 127,4 & 168,3 & 130,2 & 96,4 & 113,7 & 57,6 & 99,6 & 108,3 & 85,9 \\
\hline & Min & 0,3 & 3,4 & 1,6 & 8,8 & 19,2 & 9,4 & 0,0 & 0,0 & 0,0 & 3,5 & 0,5 & 0,9 \\
\hline & Ort. & 25,6 & 28,1 & 39,8 & 54,4 & 66,0 & 56,1 & 37,0 & 24,9 & 21,5 & 42,3 & 36,1 & 28,3 \\
\hline \multirow{3}{*}{$\begin{array}{l}\dot{\tilde{U}} \\
\dot{\tilde{a}} \\
\dot{0}\end{array}$} & $\operatorname{Max}$ & 46,0 & 63,6 & 73,7 & 115,1 & 117,5 & 91,7 & 84,1 & 62,4 & 51,6 & 97,1 & 77,2 & 54,7 \\
\hline & Min & 0,6 & 2,6 & 1,1 & 8,2 & 10,2 & 6,4 & 0,0 & 0,0 & 0,0 & 0,0 & 0,5 & 0,1 \\
\hline & Ort. & 20,8 & 23,2 & 33,4 & 49,3 & 65,9 & 43,7 & 25,8 & 18,4 & 17,2 & 38,9 & 31,3 & 24,0 \\
\hline \multirow{3}{*}{ 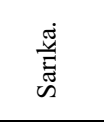 } & Max & 225,0 & 98,2 & 139,2 & 156,2 & 166,6 & 146,9 & 118,3 & 138,5 & 86,4 & 119,6 & 135,6 & 82,2 \\
\hline & Min & 0,0 & 0,0 & 0,0 & 18,6 & 10,8 & 0,8 & 0,0 & 0,0 & 0,2 & 0,4 & 0,4 & 0,0 \\
\hline & Ort. & 37,3 & 38,2 & 52,6 & 73,4 & 88,0 & 66,5 & 46,1 & 32,6 & 26,9 & 51,6 & 43,4 & 36,1 \\
\hline \multirow{3}{*}{$\stackrel{\widetilde{J}}{\mathrm{~N}}$} & Max & 103,1 & 104,8 & 135,3 & 147,3 & 169,8 & 121,6 & 45,6 & 67,9 & 71,1 & 114,9 & 171,4 & 109,8 \\
\hline & Min & 6,0 & 3,4 & 1,2 & 0,0 & 23,6 & 1,9 & 0,0 & 0,0 & 0,1 & 2,0 & 1,7 & 7,1 \\
\hline & Ort. & 46,1 & 40,2 & 52,6 & 79,8 & 73,5 & 40,8 & 10,7 & 9,4 & 20,3 & 46,0 & 49,9 & 50,2 \\
\hline \multirow{3}{*}{ 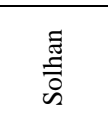 } & Max & 182,5 & 183,2 & 181,2 & 300,7 & 171,5 & 111,6 & 48,5 & 49,4 & 52,7 & 195,4 & 208,0 & 202,4 \\
\hline & Min & 2,0 & 10,5 & 21,6 & 12,9 & 9,5 & 0,0 & 0,0 & 0,0 & 0,0 & 0,0 & 0,0 & 0,0 \\
\hline & Ort. & 66,9 & 76,9 & 88,9 & 104,1 & 69,9 & 25,3 & 7,5 & 5,4 & 12,6 & 64,6 & 74,0 & 74,0 \\
\hline
\end{tabular}




\section{Ek-2: Çalışmada kullanılan akım gözlem istasyonlarına ait bazı istatistik bilgiler}

\begin{tabular}{|c|c|c|c|c|c|c|c|c|c|c|c|c|c|}
\hline İstasyon & İstatist. & Ocak & Şubat & Mart & Nisan & Mayıs & $\begin{array}{l}\text { Haziran } \\
\end{array}$ & Temmuz & Ağustos & Eylül & Ekim & Kasım & Aralık \\
\hline \multirow{3}{*}{$\frac{\tilde{\delta}}{N}$} & Max & 162,0 & 224,0 & 878,0 & 1770,0 & 1464,0 & 573,0 & 213,0 & $\begin{array}{l}95,8 \\
\end{array}$ & 73,8 & 130,0 & 259,0 & \begin{tabular}{|l}
333,0 \\
\end{tabular} \\
\hline & Min & 50,9 & $\begin{array}{l}57,8 \\
\end{array}$ & 129,0 & 79,0 & 114,0 & 39,3 & 7,0 & 14,0 & 16,4 & 36,9 & 52,1 & 37,3 \\
\hline & Ort. & 91,6 & 118,3 & 349,2 & 909,4 & 681,5 & 234,5 & 70,5 & 39,6 & 38,7 & 68,2 & 114,6 & 111,0 \\
\hline \multirow{3}{*}{$\stackrel{n}{\vec{v}}$} & Max & 125,0 & 148,0 & 247,0 & 279,0 & 163,0 & 67,8 & 42,0 & 28,8 & 25,6 & 51,1 & 89,0 & 106,0 \\
\hline & Min & 16,6 & 18,6 & 31,7 & 25,8 & 15,6 & 7,8 & 3,7 & 3,6 & 6,2 & 7,8 & 2,7 & 17,1 \\
\hline & Ort. & 54,5 & 66,8 & 99,7 & 111,7 & 71,5 & 38,8 & 24,4 & 18,0 & 16,3 & 20,1 & 27,1 & 43,9 \\
\hline \multirow{3}{*}{$\frac{\tilde{N}}{\mathrm{~N}}$} & Max & 34,8 & 43,9 & 148,0 & 292,0 & 994,0 & 168,0 & 59,7 & 31,7 & 17,6 & 32,0 & 44,3 & 34,1 \\
\hline & Min & 7,4 & 9,0 & 15,4 & 75,9 & 28,6 & 6,4 & 3,3 & 2,5 & 2,9 & 8,2 & 11,4 & 7,8 \\
\hline & Ort. & 15,0 & 16,2 & 44,4 & 176,9 & 186,0 & 63,3 & 17,5 & 9,3 & 8,5 & 15,7 & 20,2 & 17,0 \\
\hline \multirow{3}{*}{$\frac{d}{d}$} & Max & 17,6 & 17,2 & 24,3 & 50,6 & 29,4 & 22,2 & 19,4 & 18,1 & 17,9 & 18,3 & 19,4 & 18,0 \\
\hline & Min & 4,5 & 4,6 & 5,8 & 6,1 & 5,6 & 2,6 & 2,1 & 2,4 & 3,1 & 4,7 & 4,9 & 4,8 \\
\hline & Ort. & 7,2 & 7,2 & 9,8 & 14,2 & 11,2 & 8,8 & 7,2 & 6,7 & 6,8 & 7,7 & 7,8 & 7,4 \\
\hline \multirow{3}{*}{$\frac{\bar{m}}{\vec{v}}$} & Max & 2,1 & 2,5 & 10,6 & 18,1 & 8,9 & 2,8 & 2,2 & 2,0 & 2,1 & 1,4 & 1,6 & 1,4 \\
\hline & Min & 0,3 & 0,4 & 0,4 & 0,9 & 0,5 & 0,4 & 0,2 & 0,2 & 0,2 & 0,2 & 0,3 & 0,3 \\
\hline & Ort. & 0,8 & 0,9 & 2,5 & 5,1 & 2,3 & 1,2 & 1,0 & 0,8 & 0,8 & 0,7 & 0,7 & 0,7 \\
\hline \multirow{3}{*}{$\stackrel{m}{\vec{N}}$} & Max & 74,9 & 71,4 & 180,0 & 399,0 & 384,0 & 206,0 & 122,0 & 75,9 & 57,2 & 71,3 & 131,0 & 99,2 \\
\hline & Min & 19,4 & 20,5 & 40,8 & 105,0 & 86,5 & 59,7 & 37,8 & 26,9 & 22,8 & 23,7 & 19,5 & 19,0 \\
\hline & Ort. & 38,0 & 41,0 & 93,4 & 225,8 & 211,4 & 122,5 & 73,7 & 49,7 & 38,5 & 38,6 & 49,7 & 47,0 \\
\hline \multirow{3}{*}{$\stackrel{\check{c}}{\frac{n}{v}}$} & Max & 5,6 & 5,6 & 12,0 & 16,9 & 12,1 & 7,4 & 4,8 & 3,3 & 2,7 & 4,3 & 5,2 & 6,0 \\
\hline & Min & 1,5 & 1,7 & 2,3 & 2,8 & 2,7 & 2,0 & 1,4 & 1,1 & 1,3 & 1,3 & 1,4 & 1,6 \\
\hline & Ort. & 3,1 & 3,5 & 5,6 & 7,7 & 6,3 & 4,2 & 2,8 & 2,0 & 1,9 & 2,2 & 2,5 & 3,0 \\
\hline \multirow{3}{*}{$\frac{\stackrel{q}{d}}{\sim}$} & Max & 35,1 & 33,9 & 60,3 & 152,0 & 65,1 & 45,1 & 34,1 & 27,7 & 25,3 & 36,8 & 37,2 & 36,3 \\
\hline & Min & 12,5 & 13,2 & 17,5 & 17,6 & 13,8 & 12,6 & 10,5 & 10,2 & 10,8 & 13,0 & 12,8 & 12,7 \\
\hline & Ort. & 20,1 & 21,1 & 33,5 & 45,8 & 34,4 & 24,1 & 18,3 & 16,4 & 16,7 & 19,8 & 21,0 & 20,6 \\
\hline \multirow{3}{*}{$\frac{d}{n}$} & Max & 11,8 & 12,4 & 57,2 & 104,0 & 152,5 & 62,0 & 19,2 & 13,1 & 17,1 & 16,9 & 17,7 & 16,2 \\
\hline & Min & 4,9 & 5,1 & 6,3 & 18,2 & 30,7 & 5,9 & 2,8 & 2,0 & 2,5 & 3,7 & 5,5 & 4,9 \\
\hline & Ort. & 7,2 & 7,8 & 17,6 & 58,4 & 70,1 & 26,5 & 7,9 & 5,3 & 5,6 & 7,1 & 8,9 & 7,7 \\
\hline \multirow{3}{*}{ 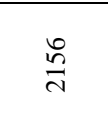 } & Max & 131,0 & 117,0 & 306,0 & 593,0 & 660,0 & 339,0 & 213,0 & 119,0 & 120,0 & 140,0 & 202,0 & 165,0 \\
\hline & Min & $\begin{array}{l}57,9 \\
\end{array}$ & 62,6 & 94,6 & 174,0 & 148,0 & 86,6 & 62,3 & 59,1 & $\begin{array}{l}55,8 \\
\end{array}$ & 64,7 & 71,3 & 66,1 \\
\hline & Ort. & 87,0 & 90,8 & 144,7 & 322,1 & 360,9 & 201,9 & 108,3 & 83,6 & 78,9 & 89,3 & 105,2 & 98,8 \\
\hline \multirow{3}{*}{$\stackrel{\infty}{\sim}$} & Max & 8,5 & 9,5 & 51,7 & 132,0 & 134,0 & 74,1 & 16,6 & 6,2 & 6,4 & 11,9 & 33,2 & 18,7 \\
\hline & Min & 3,3 & 2,7 & 5,9 & 38,2 & 20,0 & 2,7 & 1,7 & 1,5 & 1,8 & 3,5 & 2,5 & 4,3 \\
\hline & Ort. & 5,8 & 6,1 & 18,5 & 70,5 & 64,1 & 24,2 & 6,0 & 3,1 & 3,0 & 5,5 & 8,5 & 7,3 \\
\hline \multirow{3}{*}{$\frac{d}{N}$} & Max & 28,1 & 41,3 & 134,0 & 286,0 & 198,0 & 48,7 & 12,7 & 5,6 & 5,4 & 35,6 & 69,6 & 48,8 \\
\hline & Min & 6,6 & 7,7 & 18,2 & 33,5 & 5,9 & 1,3 & 0,8 & 0,7 & 1,0 & 3,7 & 6,3 & 6,7 \\
\hline & Ort. & 12,6 & 17,2 & 60,0 & 145,8 & 85,0 & 16,9 & 4,6 & 2,7 & 2,8 & 8,3 & 17,9 & 16,5 \\
\hline \multirow{3}{*}{ 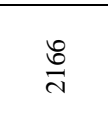 } & Max & 71,1 & 101,0 & 190,0 & 458,0 & 509,0 & 196,0 & 103,0 & 84,6 & 83,4 & 61,6 & 130,0 & 111,0 \\
\hline & Min & 7,5 & 15,9 & 34,3 & 78,1 & 50,6 & 26,9 & 2,4 & 1,9 & 1,7 & 2,8 & 3,1 & 6,4 \\
\hline & Ort. & 32,7 & 42,9 & 95,5 & 240,1 & 233,3 & 92,6 & 41,5 & 26,5 & 19,6 & 24,2 & 38,1 & 38,4 \\
\hline \multirow{3}{*}{ ֶ̊ } & Max & 31,5 & 69,1 & 151,0 & 344,0 & 179,0 & 79,2 & 22,8 & 9,9 & 10,1 & 21,6 & 86,6 & 46,0 \\
\hline & Min & 5,6 & 7,3 & 20,9 & 40,2 & 19,7 & 7,7 & 3,3 & 3,0 & 3,0 & 3,0 & 4,2 & 4,7 \\
\hline & Ort. & 14,8 & 20,4 & 76,1 & 139,7 & 88,8 & 33,8 & 10,5 & 5,6 & 5,5 & 8,4 & 13,7 & 16,8 \\
\hline \multirow{3}{*}{ ্ָণ } & Max & 7,8 & 7,1 & 25,6 & 74,2 & 99,1 & 51,7 & 24,1 & 13,7 & 10,4 & 10,9 & 13,8 & 10,9 \\
\hline & Min & 2,6 & 2,6 & 4,5 & 12,1 & 19,3 & 10,4 & 5,3 & 4,5 & 4,2 & 4,7 & 4,8 & 3,9 \\
\hline & Ort. & 5,4 & 5,3 & 8,4 & 36,9 & 52,9 & 28,6 & 12,8 & 8,4 & 6,8 & 7,2 & 7,3 & 6,1 \\
\hline & Max & 32,3 & 42,3 & 153,0 & 298,0 & 391,0 & 288,0 & 137,0 & 46,4 & 34,1 & 45,9 & 79,9 & 59,9 \\
\hline ల్ & Min & 12,5 & 13,5 & 24,2 & 71,7 & 119,0 & 72,6 & 20,8 & 11,0 & 13,0 & 2,6 & 17,8 & 13,7 \\
\hline & Ort. & 21,4 & 23,0 & 53,9 & 162,5 & 220,1 & 150,8 & 59,6 & 25,6 & 20,6 & 25,3 & 31,6 & 26,9 \\
\hline & Max & 23,1 & 43,8 & 62,0 & 126,0 & 105,0 & 29,7 & 9,0 & 5,1 & 4,9 & 10,3 & 40,3 & 53,6 \\
\hline 0 & Min & 3,5 & 5,5 & 17,3 & 15,0 & 5,8 & 3,2 & 2,2 & 2,0 & 2,0 & 2,4 & 2,5 & 3,5 \\
\hline & Ort. & 11,0 & 17,6 & 33,6 & 59,8 & 40,0 & 12,6 & 5,1 & 3,4 & 3,1 & 4,1 & 9,4 & 11,8 \\
\hline & Max & 365,0 & 391,0 & 460,0 & 596,0 & 527,0 & 255,0 & 184,0 & 83,2 & 57,5 & 109,0 & 366,0 & 408,0 \\
\hline 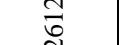 & Min & 0,2 & 0,3 & 4,3 & 106,0 & 28,9 & 7,1 & 5,1 & 0,6 & 0,2 & 1,2 & 0,3 & 0,2 \\
\hline & Ort. & 92,5 & 148,0 & 242,1 & 359,5 & 247,0 & 75,5 & 28,4 & 13,8 & 11,6 & 27,5 & 63,9 & 91,4 \\
\hline
\end{tabular}

